\title{
Al-Ghazālī's Virtue Ethical Theory of the Divine Names: The Theological Underpinnings of the Doctrine of Takhalluq in al-Maqșad al-Asnā
}

\author{
Yousef Casewit \\ Divinity School, University of Chicago, Chicago, IL, USA \\ yousefcasewit@uchicago.edu
}

\begin{abstract}
Abū Ḥāmid al-Ghazālī’s (d. 505/1111) al-Maqșad al-Asnā fì Sharh Ma ānī Asmā̄ Allāh al-Husnā ("The Highest Aim in Explaining the Meanings of God's Most Beautiful Names") is more than just a commentary on the ninety-nine names of God. In setting out to expound on a virtue ethical theory of the divine names, the Maqsad in effect amounts to a sustained theological meditation upon one of the most fundamental paradoxes of monotheism: how to locate and affirm both divine incomparability (tanzīh) and comparability (tashbih). In order to avoid any semblance of theological immanentism, or "the affirmation of God's comparability" (tashbīh), al-Ghazālī begins by positing that an unbridgeable chasm, or irreducible "disparity" (tafāwut), separates the Lord from the servant. This chasm accounts for a disconnect not only between God's unqualified Essence and the human being, but also between the transcendent meanings $(m a \bar{a} \bar{a} \bar{\imath})$ that reside in the Essence and our limited apprehension of those transcendent meanings in the mind. At the same time, he insists that this chasm does not annul the ethical relevance and ontological reality of the attributes $\left(\operatorname{ta}^{c} t \bar{i} l\right)$. Rather, the latter are somehow comparable (tashbih) and do serve as prototype for human ethical conduct. In addressing this apparent paradox, al-Ghazālī's Maqșad exudes a palpable theological anxiety. This article explores the ways in which he addresses this
\end{abstract}

* A very special thanks to my colleagues Michael Abdurrahman Fitzgerald and Kenneth Honerkamp for graciously hosting the author and his family in Ourika during the CoviD-19 pandemic. It is in their homes that much of this article was written. I am also grateful to my esteemed colleagues at the University of Chicago Divinity School for their feedback on an earlier version of this paper that was presented at the Divinity School's 2019 faculty retreat. Finally, I am indebted to Taneli Kukkonen, Mehmet Emin Güleçyüz, Susan Lee, and Ashhar Malik for their valuable feedback, and to Saiyad Nizammuddin Ahmad for his editorial assistance and hadith citations. 
theological conundrum by grounding his treatise in Ash`arī theology and Sufi ethics. It closely analyses his cautious use of diction, hyper-systematised exegetical methodology, and staunch commitment to a set of hermeneutical principles which serve to undergird his virtue ethical theory of the divine names. Later generations of commentators picked up on al-Ghazālī's theological anxiety, and critiqued the work for excessive immanentism (tashbīh), excessive transcendentalism (tanzīh), or excessive hermeneutical systematisation (takalluf).

\section{Keywords}

al-Ghazālī - virtue ethics - divine names - Ash`arism - Takhalluq - Theosis Sufism - al-Qushayrī

\section{الخلاصة}

كتاب المقصد الأسنى في شرح معاني أسماء الله الحسنى لأبي حامد الغزالي (ت. 1111/505) ليس مجرّد

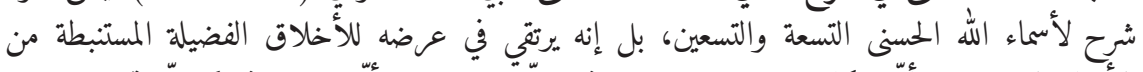

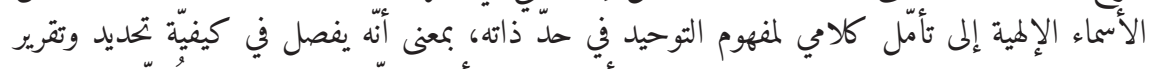

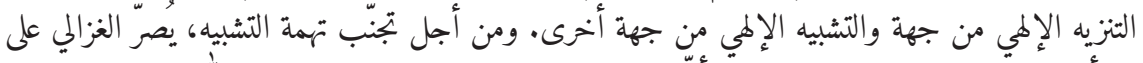

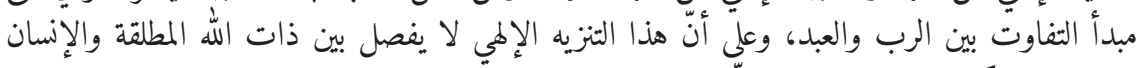

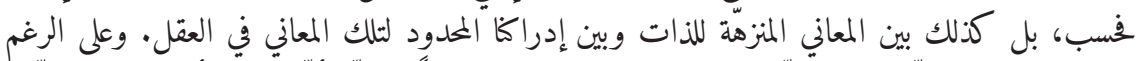

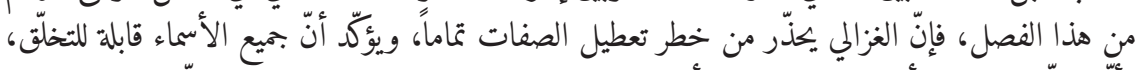

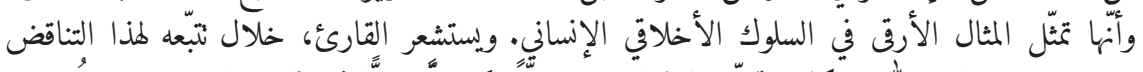

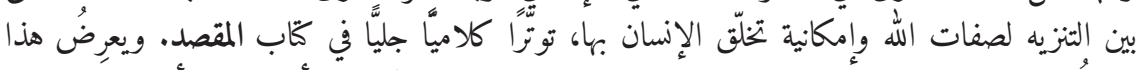

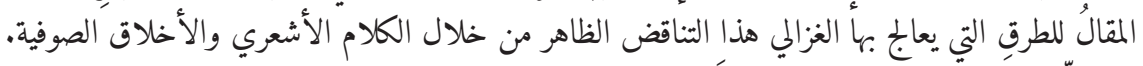

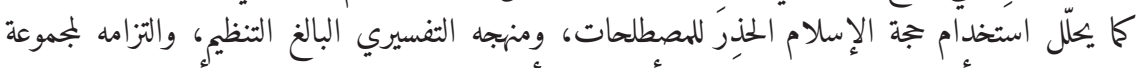

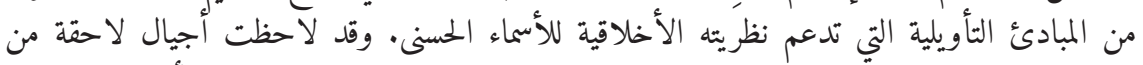

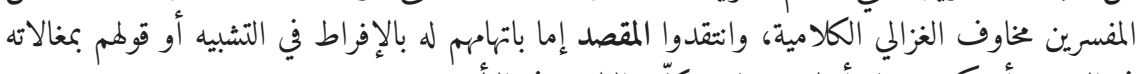
في التنزيه، أو كذلك على أساس قولمه بتكلّفه البادي في التأويل.

\section{الكلمات المفتاحية}

الغزالي - أخلاق الفضيلة - الأسماء الإلهية - الأشعرية - التخلق بأخلاق الله - التأله - التصوف - القشيري 
Al-Ghazālī (d. 505/1111) repeatedly emphasises in his writings that the intrinsic value of every branch of knowledge is judged by its subject matter. From his perspective, knowledge of God's names and attributes is the most exalted science. For its subject is God, and God is only knowable through His names, which serve as a prototype for human ethical conduct. ${ }^{1}$ Taking his lead from generations of Muslim scholars before him, and urged by multiple requests from his students, al-Ghazāli set out to expound on the theological significance and ethical implications of God's ninety-nine most beautiful names in his aptly titled treatise, al-Maqșad al-Asnā fì Sharh Ma'ānī Asmǟ Allāh al-Husnā ("The Highest Aim in Explaining the Meanings of God's Most Beautiful Names").

As an eminent theologian and Sufi ethicist, al-Ghazālī had already earned himself a wide readership when he set out to write this treatise. He was thus acutely attentive to the dangers of drawing lessons for human comportment from the transcendent meanings (ma'anni) of the divine names; or in the bold words of a purported Prophetic Tradition: "characterising oneself by the character traits of God" (al-takhalluq bi-akhlāq Alläh). ${ }^{2}$ For in contrast to deriving

1 See al-Ghazālī's discussion of the divine attributes and names in Mizzān al-'amal, authored in 488/1095, five years before the Maqșad, and prior to al-Ghazālì's departure from Baghdād. See also his Jawähir al-Qur'ān where he identifies knowledge of the Essence and attributes as the highest portion of the Qurān (al-Ghazālì 2013, 61).

2 The transmission of the purported hadith, "characterise yourself by the character traits of God" (takhallaqū bi-akhlāq Allāh) does not meet the standards of hadīth criticism, and is rejected by most hadìth experts as a forged, or baseless hadìth that has no origin (lä aṣl lahu). See for example the modern hạaīth specialist Muhammad Nāṣir al-Dīn al-Albānī (d. 1420/1999), Silsilat al-Ahâadith al-Daīfa wa-l-Mawd̄̄'a, 6:346, no. 2822 who upholds this view citing authoritative works Jalāl al-Dīn al-Suyūṭī (d. 911/1505) and Ibn Taymiyya (d. 728/1328). Al-Suyūṭī upholds this view of its having no origin in his Ta'yìd al-Haqiq a al-Aliyya which, to the best of my knowledge remains in manuscript. Evidently, al-Albānī was able to consult this work for he states that this view is stated on folio " $1 / 89$ " of Ta'yìd al-Haqiqa al-Aliyya. Ibn Taymiyya's opinion is to be found in his Talbis al-Jahmiyya fí Ta'sīs Bida'ihim al-Kalāmiyya, 6:518. Therein he too states that this hadith has no origin and further claims that the statement made in the alleged hadith is of the same class as the doctrines of "theosis" (al-tashabbuh bi-l-Bäri', al-ta'alluh) taught by philosophers and Sabian star-worshipers. Interestingly, the alleged hadìth is also quoted in Shīì sources in a similar context. See Muhammad Bāqir al-Majlisī (d. 1110/1699), Bihāar al-Anwār, 61:131 wherein he cites the hadīth in passing without giving any source. This occurs towards the end of ch. 42 of the book which is devoted to the nature of the human soul (Fì Haqīqat al-Nafs wa-l-Rūḥ wa-A ḩwālihimā) and al-Majlisī mentions that this hadith expounds a doctrine identical to that of the faläsifa, namely al-tashabbuh bi-l-iläh. At the same time, many scholars argue that the meaning of the hadith is acceptable because it is affirmed by a variety of other authentic reports and narrations and in this sense would count as being good in substance, or "affirmed by external reports" (hasan li-ghayrih). 
an ethics of action from the Qurān and Prophetic Tradition through the refined filters of jurisprudence ( $f i q h)$ and legal theory (ușül al-figh), contemplating a virtue ethics of character in light of the divine names is a much riskier undertaking. After all, God and His attributes are not analogous to anything. Humans, as he puts it, are as blind to the perfection of God's qualities as bats are to the light of the sun. Al-Ghazâli's Highest Aim is therefore to reveal the divine root of human ethics. But in reflecting upon the nature of this divine root, he would also challenge the prevalent theological approaches to the names. This in turn would force his readers to think about and relate to both the divine names, and human behaviour, in a different way, and therein lies a risk of being misunderstood (al-Ghazālī 1971, 11-12).

In order to avoid any semblance of theological immanentism, or "the affirmation of God's comparability" (tashbīh), al-Ghazāli begins by positing that an unbridgeable chasm, or irreducible "disparity" (tafāwut) separates the Lord from the servant. This chasm, or affirmation of God's incomparability (tanzī $h)$, accounts for a disconnect not only between God's unqualified Essence (al-dhät al-ilāhiyya) and the human being, but also between the meanings (ma'ānì) that reside in the Essence and our apprehension of those meanings in the mind. Yet, in spite of this chasm, he affirms at the risk of denying the attributes ( $\left.t a^{c} t \underline{i} l\right)$ altogether, that the names are somehow comparable (tashbih) and do serve as prototype for human ethical conduct. Divine mercy, for instance, is comparable to human mercy not only in a metaphorical sense (majäz) or because both divine and human traits are described univocally, i.e. by the same word (ishtirāk laf:īi), but also in a spiritual sense that goes beyond semantics. The servant, he argues, experiences three stages of grace, or "shares" (sing. hazz) in the names in progressive stages as he increases in self-knowledge. The first is to cross from abstract belief in a name to concrete certitude of it. For instance, a servant may understand God's power by experiencing his own utter helplessness. The name the Powerful thus becomes immediately evident through "demonstrative unveiling" (inkishāf burhānī). This demonstrative unveiling

Many sound and weak reports invite the servant to assume the traits of God, and as such, the takhalluq tradition is used not as a prooftext but a catch-phrase in the Maqșad and other commentaries on the divine names to refer to this cluster of more reliable scriptural references. According to al-Qushayrī, the expression is found in God's statement to His prophet David: "Characterise yourself by My character traits" (takhallaq bi-akhlāqū) (al-Qushayrī 2003, 310). This statement is ascribed to al-Wāsīṭī and cited by al-Sulamī in his Haquảiq (Gramlich 1995, 407). The expression is ascribed in various forms to a number of early figures including 'Uthmān Ibn 'Affān (d. 35/656), al-Ḥasan al-Bașrī (d. 110/728), Dhū l-Nūn al-Mișrī (d. 245/859 or 248/862), Sahl al-Tustarī (d. 283/896), al-Hakīm al-Tirmidhī (d. ca. 318/936), Abū Bakr al-Wāsițī (d. ca. 320/932), Abū 'Abd al-Raḥmān al-Sulamī (d. 421/1021) (Chiabotti 2017, 170-177). 
gives rise to an ineluctable certainty and an irresistible attraction toward the beautiful names, provided that the heart is purified of worldly attachments. Finally, the name's magnetic appeal draws the servant to a state of proximity (qurb) to the angels and culminates in the bewildering realisation that only God actually knows God, and that the servant knows His Lord only insofar as he knows himself.

As it turns out, al-Ghazālī's Maqșad is more than just a commentary on the ninety-nine names of God. It is a sustained meditation upon one of the most fundamental paradoxes of monotheism: how to locate and affirm both divine incomparability and comparability. For although God's incomparability (tanzīh) may seem easier to speak of than His comparability, both pose baffling theological conundrums for al-Ghazālī. How is it even possible for a human being to affirm God's absolute transcendence and utter incommensurability? Is not the very act of drawing a hard line between what is unknowable and transcendent in God, and what is recognisable and immanent in Him, a qualification and restriction of sorts that compromises God's absoluteness? That is, how can we even demarcate what we can and cannot know without some sort of recognition of what lies on both sides of the boundary? Furthermore, since we can only know and relate to God in terms that are familiar to us, aren't we merely calling God transcendent or immanent through our subjective human prism? If this is indeed the case, and if we are the very boundary that separates our understanding of God from God-in-Himself, then by recognising the cognitive limitations of our knowledge of the divine, do we not also hint at something beyond the boundaries of our cognitive abilities?

Many Sufis have responded to these apparent contradictions by evoking the servant's annihilation in $\left(\right.$ fan $\left.\bar{a}^{\prime}\right)$ and subsistence through $\left(b a q \bar{a}^{\prime}\right)$ the Lord, thereby collapsing the servant-Lord binary. Al-Ghazālī, as a Sufi theologian with a broad readership, refuses to blur those lines. As a result, the Maqșad exudes a palpable theological anxiety. In laying out a theological framework for the divine roots of human ethics, al-Ghazālī privileges the servant's proximity to an angelic ideal. He does not hold God as such, nor Adam's primordial perfection (kamāl âdamī as Ibn 'Arabì would put it), as the human ethical ideal. Although he grounds his treatise in Ash'arī theology and Sufi ethics, his anxiety is palpable in his cautious use of diction, and a hyper-systematised approach to interpreting the divine names, and a staunch commitment to a set of semantic and hermeneutical principles that undergird his ethical project and create a space for it to operate within the boundaries of Ash'ari theological orthodoxy. These principles include his semantic theory of non-synonymity of the divine names, an Avicennan-inspired notion of the names' transcendent meanings (sing. $m a^{\prime} n \bar{a}$ ), and Ash'arī volitionism. Later generations of commentators 
picked up on al-Ghazâlī's theological anxieties, and critique the work for excessive tashbïh, excessive tanzīh, or excessive hermeneutical systematisation (takalluf).

\section{Genre and Precedents}

Like most authors who contributed to this contemplative genre of religious literature, al-Ghazâlī was already a mature scholar when he set out to write the Maqșad around 495-499/1101-1105, sometime during his period of retreat in Ṭūs. His monumental spiritual-ethical project, Ihy à ' Ulüm al-Dìn ("The Revival of the Religious Sciences") had recently been completed and was still fresh in his mind. Moreover, he had yet to return to public teaching in Nīshāpūr by $499 / 1105,{ }^{3}$ although parts of the Maqsad were clearly composed in conversation with a small circle of students. Setting aside the obvious differences of size and scope between the voluminous Ihy $\bar{a}$ and the much smaller Maqsad, both works are broadly comparable in several ways.

First, the Ihyya and the Maqșad are fundamentally interested in character transformation: the cultivation of virtue and the cleansing of vice. Both works build upon the efforts of previous scholars, such as al-Āmirī (d. 381/992) and al-Rāghib al-Iṣfahānī (d. 502/1108), who brought their knowledge of philosophical ethics to bear upon religious literature, and vice versa. Al-Ghazālì's background in works of jurisprudence, Ash'arī theology, and Sufism such as al-Makkī's (d. ca. 386/996) Qüt al-Qulüb ("Nourishment of the Hearts") is evident in the Ihy $\bar{a}^{\prime}$ and the Maqsad. Both can thus be classified as works of "normative religious ethics," to use Hourani's classification of Islamic ethics. They are "normative" in their marked reliance on transmitted wisdom coupled with rational argument, in contrast to strictly "analytical" works of ethics such as Miskawayh's (d. 421/1030) influential Tahdhīb al-Akhlāq ("Refinement of Character Traits"), a treatise that prioritises rational deliberation over scriptural guidance. Both are also "religious" works that rely heavily on scripturalQur'ān, Prophetic Tradition, Sufi manuals, and jurisprudence ( figh) - rather than "secular" or non-scriptural sources such as proverbs, poetry, or books of advice for kings (Zargar 2017, 79-80).

Thus, both works are ethical projects that are built on the premise that revelatory guidance is indispensable to the field of ethics and religious practice. Ethical conduct cannot be arrived at through rational demonstration and

3 Al-Ghazālī cites the Iḥyā’ in the Maqșad (e.g., al-Ghazālī 1971, 115, 127), and the Maqșad in the Munqidh min al-Daläl which was composed at least one year after the Maqșad in 500/1106. 
apodictic proof (burhān). It must be directed by scriptural guidance, at whose heart lies the divine names, because the rationalising intellect does not function in a sound manner if the heart is impure. Although praiseworthy virtues pre-exist in the innate disposition of the human being ( fitra), the blameworthy vices, which are accidental to it, can impair the intellect. As such, the intellect cannot rediscover the human being's innate disposition on its own, since it is easily over-clouded by and rendered in the service of uncontrolled appetites. Thus, the unaided intellect cannot reason its way to spiritual purification, character perfection, or divine realisation (al-Ghazālī 1971, 11, 55).

Despite shared similarities, the Maqșad is arguably a more theologically and scripturally confined ethical project than the Ihy $\bar{a}^{2}$, and as such it differs in approach and organisational presentation when compared with the Ihya $\bar{a}^{\prime \prime}$ discussions of the cardinal virtues. In the Maqșad, he commits himself to a set of theologically-informed hermeneutical principles that he consistently adheres to throughout the text. Moreover, the virtues that he discusses are sequentially ordered according to their order of appearance in the Prophetic Tradition of the divine names narrated by Abū Hurayra (d. ca. 58/678). ${ }^{4}$ The Maqșad thus

4 The hadith that lists the ninety-nine names has a rather complex transmission and reception history. The text (matn) is narrated ( $r \bar{a} w \bar{\imath})$ on the authority of Abū Hurayra and contains two parts. The first part reads: "Verily God has ninety-nine names, whoever reckons them (man $a h s ̦ \bar{a} h \bar{a})$ enters the Garden." This statement is transmitted through multiple chains of reputable Followers (tābi īn) and is listed in the soundest hadith collections. In most reports, the prophetic invitation to reckon (ihșa $)$ ) the ninety-nine names is followed by a second part that lists the ninety-nine names. It is this second part that the narrations of the hadith generally differ. Abū Hurayra's hadīth is narrated by way of (tarīq) three transmitters: (1) 'Abd al-'Azīz b. al-Ḥuṣayn (weak), (2) 'Abd al-Malik b. Muhammad al-Ṣan'ānī (weak); (3) and al-Walīd b. Muslim (soundest-but still a weak hadith with two to four intermediaries on the chain). Within each of the lists, there are considerable discrepancies. These discrepancies are understandable given that the oral transmitters retained the first portion of the hadith, but could not retain all the names in the list. However, the lists are not always ascribed to the Prophet and are considered by many hadith authorities to be interpolations (mudraj) added by the transmitter $(r \bar{a} w \bar{\imath})$, in this case, by al-Walīd b. Muslim from his hadìth teachers. Al-Ghazālì bases his Maqșad on the locus classicus of this celebrated hadith narration found in the collection of al-Tirmidhī wherein we find four narrations. His hadith narration goes through al-Walìd b. Muslim and the names in the list are considered to be weak. Moreover, there are names in Tirmidhì (e.g. the Lord $a$-Rabb; et al) that are not mentioned in other lists. See Muḥammad b. 'Īsā b. Sawrah al-Tirmidhī (d. 279/892), Sunan, 2:899-9oo, no. 3847, 3848, 3849 , and 385 o. Of these it is only no. 3849 , related by Abu Hurayra, which actually lists the 99 names discussed by al-Ghazālī. The list is found in this form only in al-Tirmidhì's Sunan. The isnād is Ibrāhīm b. Ya'qūb al-Jūzjānī—Ṣafwān b. Șālị̣—al-Walīd b. Muslim—Shu'ayb b. Abī Ḥamza-Abū l-Zannād—al-A'raj—Abū Hurayra. It is also to be found in three places (with varying isnāds but all going back to Abū Hurayra but without listing the 99 names) in Muḥammad b. Ismā̄îl al-Bukhārī (d. 256/87o), Șaḥịh, 1:527-528, no. 2774; 3:1302, no. 6485, 
serves both as a concise supplement to the I $h y \bar{a}$, and an alternative way of approaching the field of Islamic virtue ethics. The virtues in the Maqsad are broader in scope than those presented in the Ihy $\vec{a}$, since they are based on names of the divine Essence. At the same time, they are treated with less depth than the cardinal virtues are in the Ihy $\bar{a}$.

Tellingly, the idea of deriving ethical guidance from the divine names is already discussed and theorised to a limited extent in the Ihyä.$^{5}$ However, the theological consequences of this ambitious project are only fully worked out in the Maqșad. The Ihy $\bar{a}^{3}$ tends to focus on, but not limit itself to, the ethical consequences of the positive or beautiful traits of God, such as generosity, kindness, mercy, and knowledge, for these obviously set an ethical ideal for human comportment. Who would question the ethical relevance of, say, the famous Prophetic Tradition: "The merciful are treated mercifully by the All-Merciful"?6 The names of divine majesty and transcendence, such as the Exalted or the Avenger, however, tend to be less invoked for ethical purposes. Thus, what is absent from the Ihyä), but present in the Maqsad, is a detailed exposition of theologically informed virtues that stem from the full spectrum of divine names and attributes, and a systematic and coherent framework to derive ethical knowledge therefrom.

\section{$3 \quad$ Situating the Maqșad}

Al-Ghazāli was not the first to produce a sustained meditation on the divine roots of human ethics (takhalluq), nor does he claim to be. In fact, the Maqșad

and 3:1492-1493, no. 7841. There are also two places (again with varying isnāds but all going back to Abū Hurayra but without listing the 99 names) in Ahmad b. Hanbal, al-Musnad, 3:1578, no. 7618; III:1599, no. 7738. Finally, it is also to be found in two places (again with varying isnāds but all going back to Abū Hurayra but without listing the 99 names) in Muslim b. al-Ḥajjāj al-Naysabūrī (d. 261/874), Șahịh, 2:1133, no. 6985, 6986. See also Jamāl al-Din Yūsuf al-Mizzī (d. 742/1342), Tuhfat al-Ashräf, nos. 14,674; 14,536; 13,727; 13,674.

5 There are several substantial discussions of the theory of takhalluq in the Ihyä. See his "Book on Poverty and Renunciation" under the heading "On the excellence of poverty over affluence" (bayān fadilat al-faqr 'alā l-ghinā); and his "Book on Love" (kitāb al-mahabba), under the heading "Making clear that God alone is worthy of love" (bayān anna l-mustahiqq li'-mahabba huwa Allāh). In line with al-Makkī, al-Ghazālī describes fasting as "an assumption of the divine character trait of self-sufficiency (șamadiyya)" in his "Book on the Secrets of the Fast" (asrär al-șawm).

6 This hadith, known as the hadìth of Mercy (al-Rahma) or al-hadìth al-musalsal bil-awwaliyya (lit. "The hadìth that is narrated first") is traditionally the first hadith that is taught to children, and it is customary for hadìth lessons to begin with it. Al-Tirmidhī categorises it as hasan șahịh in his Sunan (kitāb al-birr wa-l-șila). 
displays a marked dependence upon an already well established and independent genre of religious literature: the divine names tradition. He demonstrates an awareness of this tradition in general, and is heavily indebted to al-Qushayri's (d. 465/1074) ground-breaking commentary, al-Tahbir fi Tlm al-Tadhkìr ("The Adornment of the Science of Exhortation") in particular (Gimaret 1988, 2526; Ayed 1983, 295-298). This work, which was penned prior to al-Qushayri's Sufi handbook, al-Risāla, as well as his Sufi exegesis Lațāif al-Ishārāt, provides the theological, Sufi, and ethical basis for al-Ghazāli's ethical theory of the divine names in the Maqșad. It also influenced other similar works of the 6th/ 12th century. ${ }^{7}$ In a sense, al-Qushayrīs Tahbir is as theologically, mystically, and ethically foundational to the Maqșad as al-Makkî's Qūt al-Qutūb is to the Ihy $\bar{a}$. It is the insights that al-Qushayri compiles in his commentary on the names that are featured most prominently in the Maqșad.

The Tahbir, for its part, is a synthesis of at least three major interpretive vectors, namely philological, theological, and Sufi. The first vector is exemplified in philological commentaries (shurūh lughawiyya), such as Sha'n al-Du'ä’ ("Matters Concerning Supplication") penned by the Shāfiì scholar al-Khațtābī (d. 388/998). Such works are predominantly lexicographic exercises in uncovering the variety of meanings of each divine name. ${ }^{8}$ They function as precursors to the second vector seen in theological texts, such as al-Bayhaqi's (d. 458/1065) classic, al-Asmä $\bar{a}^{2}$ wa-l-Sifät ("The Names and Attributes"). ${ }^{9}$ This work takes the

7 Qushayrì's Tahbìr is extensively cited by al-Sam‘ānī (d. 535/1140) in his massive Persian commentary on the divine names. See Chittick's introduction to The Repose of the Spirits (Rawh al-Arwāh ) (al-Sam'ānī 2019).

8 The earliest lexicographic compilations, including al-Khalīl b. Ahmmad's (d. 170/786) Kitāb al-'Ayn, already showcase linguistic discussions of the divine names. Important in this context is Abū Ishāq al-Zajjajj's (d. 311/923) short treatise, Tafsīr al-Asmāà, which consists of linguistic analyses of the divine names from al-Tirmidhī's list, with references to relevant verses of poetry and scriptural prooftexts. Building upon the latter, Abū l-Qāsim al-Zajjajjìs (d. 340/951) Ishtiqāq Asmā' Allāh ("Etymological Derivations of God's Names") highlights the etymological roots of the names and incorporates materials from tafsir literature into his commentary. Divine names commentaries also build on definitions in Abū Sulaymān al-Khaț̣ābī's (d. 388/998) Sha'n al-Du'ä' ("Matters Related to Supplication”), a work on the proper etiquette $(a d a b)$ of supplication with an important section dedicated to linguistic analysis of the names, which was popular in al-Andalus. Furthermore, al-Farrā”s (d. 207/822) Ma'ānīl-Qurāan ("The Meanings of the Qur'ān") and al-Ṭabarìs (d. 310/923) Qurān exegesis are important early linguistic sources, as is Ibn Fāris' (d. 395/1004) Arabic lexicon, Maqāȳ̄s al-Lugha.

9 Al-Bāqillānī (d. 402/1013) wrote his work from an Ash'arī perspective, building upon al-Khațāābìs Sha'n al-Du'ā’ and a section on the names from al-Halīmī's (d. 403/1012) threevolume theological work, Shu'ab al-İmān ("The Branches of Faith"). Prior to al-Bāqillānī, treatises and chapters on the divine names were usually included within larger theological works, such as Ibn Khuzayma’s (d. 311/923) Kitāb al-Tawhìd ("Book on Divine Oneness") and 
earlier philological discussions as its starting point and tries to work out the meanings of the names within the Ash'ari school of theology. The theological texts, for their part, were often penned by Sufi-inclined theologians. These authors were attentive to the fact that analysing the ultimacy of God's names and attributes also generates an awareness of His intimacy. Thus, al-Qushayrī, and al-Ghazāli in his wake, exemplify the third vector in bringing their expertise in Sufism to bear upon the divine names tradition.

From a broader historical developmental perspective, it is also important to emphasise that the Maqsad still represents a relatively early text in the genre. It lacks at least two important approaches to the names which had yet to be formulated and absorbed into the mainstream divine names commentaries for obvious historical reasons. One is the ontological turn in the tradition that was instigated by Ibn 'Arabī (d. 637/1240) and his students, who engage with the names not from an Ash'arī volitionist perspective but as ontological relationships (sing. nisba) between God and creation. This ontological turn raises a host of new questions, and solves some of the theological anxieties that are so clearly palpable in the Maqșad. Thus, whereas al-Ghazāli treats names like the Ever-Merciful (al-Rahīm) or the Inflictor of Harm (al-Dārr) as aspects of God's will to bless or punish a servant, Ibn 'Arabī and his school prioritise the servant's subjective response to God's singular reality depending on his capacity, or "preparedness" (isticdād) for that encounter. The servant responds to the disclosed properties of these contrary names, displaying "agreeability" (mulāama), "disagreeability" (munāfara), "readiness" (tahayyu'), or "preparedness" (isti'dā $d$ ) for the divine self-disclosure. As such, God as "The Inflicter of Harm" is really a manifestation of an unprepared servant's response to His disclosure. Al-Ghazāli briefly evokes the concept of "agreeability" in the Maqșad. ${ }^{10}$ But he prioritises Ash'arī definitions of divine mercy and wrath as God's will to bless or punish in order to avoid the implication that God is qualified by imperfect human emotions and psychological states. In contrast to the Ash'arīs, 7th/13th century commentators like Ibn 'Arabī, al-Qūnawī (d. 672/1274), and 'Afíf al-Dīn al-Tilimsānì (d. 69o/1291) equate divine mercy (raḥma) with the act

Ibn Manda's (d. 395/1004) Kitāb al-Tawhīd wa-Ma'rifat Asmä’ Allāh ("Book on Divine Oneness and Knowledge of God's Names"). Other important theological material on the names is found in 'Abd al-Jabbār's (d. 415/1025) summa of theology al-Mughni, al-Khațīb al-Baghdādī’s (d. 463/1071) Qur’ān commentary; al-Juwaynī's (d. 478/1085) Kitāb al-Irshād; al-Bayhaqī's (d. 458/1066) I'tiqād and al-Jāmi' li-Shu'ab al-İmān; and Ibn Fūrak's (d. 406/1015) Mujarrad (Gimaret 1988, 15-35).

10 See al-Ghazālì's discussion of the name the Majestic (al-Jalīl), and the perception (idrāk) of God's beauty and majesty (al-Ghazālī 1971, 126). 
of creation $(\bar{j} j \bar{a} d)$ and privilege the doctrine of the Breath of the All-Merciful (nafas al-Rahmmān).

In addition to this ontologising approach, the Maqsad is also virtually devoid of a second approach: occult meditations on the names and the symbolism of the letters ('ilmal-jafr). These approaches-which are both an outcome of the ontological turn in the tradition and a result of the re-introduction of elements within early Sufi thought that were cautiously filtered out of the classical Sufi treatises up to al-Ghazâli's time-occupy an important place in commentaries written after the 7 th $/ 13$ th century. Instead of emphasising the ethical implications of the names, later commentators also tended to include discussions of the talismanic, magical, and healing properties of the names as remedies to ailments in the soul. These remedies, which are acquired by invoking the names, are a common feature of divine names commentaries in the later Islamic Middle period. Traces of this discourse are found in earlier Sufi and Shīi i texts, and are featured prominently in al-Būnì's (d. 622/1225) writings, but are completely absent from the Maqșad. From a broad historical perspective, therefore, the Maqșad can be defined as a work of "theological Sufism" that prioritises and synthesises three early interpretive strands in the pre-Ibn 'Arabī commentary tradition: philological, theological, and Sufi-ethical.

\section{4 \\ Structure of the Maqșad}

Structurally, the Maqsad is a compilation of three distinct parts, or disciplines ( funūn), and each part of the book consists of self-standing chapters ( $a b w \bar{a} b$ ). The first three chapters act as a prelude to the commentary on the names and set forth al-Ghazālì's hermeneutical principles. They stand as buttresses against excessive tashbìh and tanzīh, and create space for his theory of takhalluq to operate within the bounds of Asharism. Setting these chapters aside, al-Ghazālì's actual commentary on the ninety-nine names is quite short and concise, spanning less than one hundred pages in Shihadeh's 1971 edition. It is certainly the longest chapter of the Maqsad, but is relatively short when compared to the fifty-page introductory discussions of the Maqsad or to other voluminous works. ${ }^{11}$

11 Compare with commentaries by al-Qushayrī, Ibn al-Uqlīshī, Ibn Barrajān, or Abū Bakr b. al-'Arabī. Moreover, the text features various types of subheadings, such as a "subtle point" (daqīqa) that usually offer a theological insight; a "beneficial tip" ( fä̀ida) regarding a name; or a moral hortatory section (tanbīh) where the servant's "share" in a name is typically discussed. The Maqșad even features question-and-answer sections which al-Ghazālī likely wrote after oral interactions with students during his composition of the 
Al-Ghazālī typically comments on each entry bottom-up. He begins by offering a very succinct philological explanation of a name, which he then captures conceptually and transposes on to the divine plane to give a sense of its transcendent meaning and theological implication. He often illustrates the mána of a name through a brilliant metaphor or allegory, and stresses dissimilarity and non-qualification of God throughout. For some names, such as the Reckoner (al-Hasib) in the hereafter, he proclaims that the name is almost completely inaccessible and unobservable since its meanings have yet to be fully disclosed. Al-Ghazālī also stresses that it is not enough to grasp the linguistic-morphological analysis of a divine name (ishtiqāq), or even to imagine its pure, supra-formal, supra-sensory meaning (tawahhum al-ma'nā); what is necessary is the realisation (tahquiq) and witnessing (mushähada) of the names (al-Ghazālī 1971, 122). Having said that, al-Ghazālī then offers his reflections on cultivating its ethical properties.

\section{Modes of Consolidation, Filtration and Self-Censorship}

One of al-Ghazālī's main goals in this work is brevity, clarity, and concision. This he achieves with remarkable eloquence and often in rhyming prose. Many of al-Ghazālì's concise entries are summaries of al-Qushayrì's lengthier entries. These borrowings are so frequent that they are hardly worth citing, and a brief comparison between the two texts is sufficient to show the extent of his indebtedness to the Tahbīir. However, al-Ghazāli’s ethical insights are selectively appropriated and abridged from the Tahbir on the basis of his theological priorities. As a result, the names that receive shorter commentaries in the Maqșad tend to be heavily informed by the Tahbirr, whereas the names that al-Ghazāli dwells upon at length tend to be his own original compositions. Although it may be tempting to assume that the Maqșad is most original in these long tangents because they mark a clear departure from al-Qushayri's commentary, ${ }^{12} \mathrm{I}$ would argue that the instances of filtration and synthesis are equally revealing of al-Ghazâlī's authorial creativity.

text. Furthermore, internal cross-references within the treatise indicate that the Maqsad was written sequentially from beginning to end, a fact which would explain some of the inconsistencies between the introductory chapters and the concluding chapters over the question of whether or not the divine names are limited to ninety-nine.

12 See for instance his extensive discussion and illustrative examples of the All-Preserving (al-Hafiz), and how God preserves a drop from evaporating by means of an angel (al-Ghazālī 1971, 119-22). 
Al-Ghazâlī's departures from the Tahbir feature themes and sections that excite him and he cannot resist devoting more attention to them (al-Ghazālī 1971, $75,92,101)$. For instance, al-Ghazāli gives special attention to the problem of theodicy under the names the All-Merciful (al-Rahmānn) and the Ever-Merciful (al-Rahīm) (al-Ghazālī 1971, 67), explaining how God is Ever-Merciful yet permits so much misery in the world. Or again, the name the Determiner (al-Hakam) features an extended and ingenious water clock metaphor to illustrate how God engineers the cosmos, while and the name the Exalted (al-'Alī) receives extensive discussion on spatiality, and what it means to say that God is not spatially determined or qualified (al-Ghazālī 1971, 115-118). Al-Ghazālī is also keen to provide detailed explanations of the concept of divine governance (tadbìr), decree ( $\left.q a d \bar{a}^{\prime}\right)$ and determination (taqdīr) (al-Ghazālī 1971, 98-105).

The shorter condensations of al-Qushayrīs work feature patterns of theological filtration, synthesis, and selective appropriation. The first mode of synthesis is simply when al-Ghazālī wishes to be brief (al-Ghazālī 1971, 136), or to avoid redundancy (al-Ghazālī 1971, 140) or to avoid stating an obvious point (al-Ghazāli 1971, 146). He dispenses with the poetry, the anecdotes, the scriptural roots of the names in the Qur'ān, and instead offers his own illustrative metaphors. When he senses that more discussion is in order, he typically points his reader to a relevant book in the Ihy $\vec{a}^{\prime}$ or to a different divine name within the Maqșad. In other instances, however, one detects the suppression of material that the author considers to be theologically objectionable or rationally inchoate. For instance, he finds much of the accumulated material on the name the Light ( $a l-N \bar{u} r$ ) to be vague, incoherent, and not worth engaging. Thus al-Ghazālī brushes this genre of mystical reflection aside and provides his own tightly framed insight. (al-Ghazālī 1971, 158).

In some cases, al-Ghazālì chooses to be succinct in order to filter out mystical discussions that he seems to approve of, but which he considers to be too esoteric to be divulged in his book (al-Ghazāli 1971, 134). These moments of self-censorship are meant to be revealing, at least to the educated reader, since he informs the reader that he is cautiously filtering out material from the text. These instances also suggest that like the Ihyya , al-Ghazâlī wrote the Maqșad for a broad readership. For instance, in his discussion of the names the Powerful (al-Qādir) and the Potent (al-Muqtadir), al-Ghazālì ends his discussion with the tight-lipped statement: "and beyond this lie depths that a book such as this one cannot bear" (al-Ghazālī 1971, 145). This seems to suggest his tacit approval of statements by early Sufis such as al-Tustarī (d. 283/896) who blur the lines between the annihilated servant and the eternal Lord. Al-Tustarī speaks of himself as having aligned his desires with God's will to the extent that the divine-human volitional binary is no longer discernible and the servant 
acts by and through God's will. Al-Tustarī proclaims Qur'ānic verses, such as God's command is to say be and it is, as being applicable to himself since he is completely aligned with God's will. Al-Ghazālì seems to tacitly approve of this idea of complete annihilation in God's will, but considers it to be too risky, confusing, or misleading to share in his treatise.

Al-Ghazālī's authorial resourcefulness is also on full display in his discussions of polysemic names of God. His linguistic definitions of these names are typically based on selections from al-Qushayrì's text. However, al-Ghazālī puts philology in the service of theology and his selection process is guided by his theological priorities. For instance, when al-Qushayrī explores polysemic names like the Guardian (al-Muhaymin), he offers several definitions and notes how several of its meanings converge with other names such as the Watchful (al-Raqīb), the Preserver (al-Hāfiz), or the Trustworthy (al-Aminn). Having set the stage, al-Qushayrī enters into a multifaceted theological and ethical discussion of the name. In contrast, al-Ghazāli begins with the a priori theological assumption that each name only carries one meaning (see below), and his discussion of al-Muhaymin is framed in such a way that the meanings of other names do not overlap with it.

In addition to the theological filters that al-Ghazāli imposes upon philological discussions, he is also dismissive of certain classical discussions that typically attract extensive commentary. These departures from convention are revealing as well. For example, lengthy discussions over whether the allencompassing divine name Allāh (al-ism al-jāmi $)$ is etymologically derived from a triconsonantal Arabic root receive lengthy treatment in al-Qushayrī and other commentaries. Discussions over the dozen possible roots of Allāh tend to span several pages in the major commentaries and offer a space for reflection. But the debate is dismissed in the Maqșad as futile and passed over in silence. Whereas an author like al-Qushayrī would capitalise on the plurality of meanings and possible etymological roots to reap abundant theological and ethical insights, al-Ghazālì sees such discussions as opening the door to arbitrariness. These discussions complicate his ethical project which relies on a stable set of semantic principles (non-synonymity, monosemy); i.e., that each divine name can only be associated with a single meaning and must have a single root. Following al-Juwaynī's (d. 478/1085) lead in the Irshād (al-Juwaynī 1950, 144), he simply states:

It seems most likely that the denotation of this name follows according to the manner of proper names; thus everything that has been said about its etymological derivation and its [multiple] definition[s] is arbitrary and artificially imposed.

AL-GHAZĀLĪ 1995, trans. BURRELL and DAHER with some modifications, 51 
Likewise, in contrast to the theologically rigorous foundations of the Maqșad, al-Ghazālī has little interest in engaging in debates over the Qurānic or hadith foundations of the names, and his discussions of this topic are rather inconsistent and lacking in rigor. He does not devote much attention to the complicated transmission history of the divine names in the Prophetic Tradition. Like many early commentaries of the period, he is content to sequence his commentary according to the order of appearance of the names in Abū Hurayra's narration as it is transmitted by al-Walīd b. Muslim (d. 194/810) in the Sunan collection of al-Tirmidhì (d. 279/892). This list of names, which is not arranged theologically, follows roughly their patterns in the Qurān where pairs of names are often mentioned sequentially.13 Moreover, al-Tirmidhï's is one among several lists, and it omits key divine names that are affirmed by the Qur'ān such as the Only (al-Ahad) vs. the One (al-Wähid).

Toward the end of the Maqșad, al-Ghazâli confesses that the ninety-nine names on his list are not necessarily the ones that the Prophet intended when he stated that God has ninety-nine names. He affirms that the names are somehow ninety-nine, even as he acknowledges that the number of names that have come down to us through the different famous narrations (riwāyāt) far exceeds that number. ${ }^{14}$ Likewise, if one were to derive divine names from Qurānic verbs and acts ascribed to God, then the list would grow beyond ninety-nine. He appeals to using this list following the convention of the genre since it is the most famous narration. ${ }^{15}$ While many post-Ghazālian commentators were keen to comment on as many names as they could track down in scripture, al-Ghazālī chooses to apply his rather rigid theological framework for takhalluq on a stable inventory of divine names. Later generations of commentators attempt to cover as many names as possible, and try to comment on every possible name transmitted to us. In contrast, al-Ghazālī is primarily attentive

13 E.g., the Source of Safety (al-Mu'min) and the Guardian (al-Muhaymin), or the Living (al-Hayy) and the Self-Sustaining (al-Qayyüm).

14 Sufyān b. 'Uyayna (d. 198/813-4) and other scholars have derived ninety-nine names from the Qur'ān, and Ibn al-Uqlīshī lists these names and their location in the Qur'ān (Ibn al-Uqlīshī 2017, 1:177). 'Afîf al-Dīn al-Tilimsānī apparently structures his commentary on the names on the basis of Ibn 'Uyayna's list.

15 In his conclusion to the first chapter ( $f a s ̣ / 1$ ), al-Ghazāli holds that the names are not numerically limited (mahșūr) by the hadīth of ninety-nine names, since many names that are mentioned in the Qur'ān and hadith are not in the list. However, in the second chapter ( fașl 2), al-Ghazālī attempts to demonstrate the benefit of specifying ninety-nine names, and here he seems to contradict himself regarding whether there are ninety-nine names or more. Then in part three ( fann $_{3}$ ) he holds that the names are not confined to ninetynine. Al-Ghazāli's thought seems to have evolved over the course of his composition of the text. 
to the theological hermeneutics that guide his approach to the names, and therefore devotes relatively little consideration to their scriptural foundations. ${ }^{16}$

\section{The Semantic Foundations of Takhalluq}

\subsection{Semantic Theory}

In line with a number of previous commentaries on the divine names, including al-Qushayrì's, al-Ghazāli devotes Chapter One (al-fașl al-awwal) of the Maqșad to stake out his position on the debate over the theory of signification; that is, whether the name (ism) of a thing is identical to the thing-in-itself ('ayn al-musammā), or whether they are distinct. Here, al-Ghazālì's theological framework is truly original. It should be noted that in entering into this discussion, al-Ghazâlī is engaging in a discourse that has Greek precedents and a long genealogy tracing back to debates between Arabic grammarians as well as the Ahl al-Hadìth and the Mu'tazili theologians (Maghsoudlou 2017). For the latter, semantic debates had a bearing upon such questions as the createdness or eternity of the Qur'ān, and whether the essential attributes (Life, Knowledge, Power, Will) are positive attributes that are superadded to the Essence $(z \bar{a}) i d a$ 'alā l-dhāt) and coeternal with It, or whether they are negative attributes that are original to It. References to the theory of signification are noted already by al-Ṭabarī (d. 310/923) who quotes Ahmad Ibn Hanbal (d. 241/855) as the earliest traditionist to respond to the Mu'tazili claim that the name and the named are distinct. Other early traditionists, including al-Ṭabarī and Ibn Hanbal's disciple, Ibrāhīm al-Ḥarbī (d. 285/898), refrained from this debate altogether and dismissed it as a futile waste of time.

For Mu'tazilīs, this debate was anything but futile. In the simplest terms, affirming that the name is other than the named, or that God is other than His names, for them entails that the divine names are created, and this was a case in point for their arguments over the createdness of the Qurān. In other words, Mu'tazilis insist that the names are vocables, or temporally originated and uttered words (sing. lafz hădith). They are non-eternal, hence created, just like the Qurān, for God did not call Himself by them in pre-eternity (azal). This position is, according to many early and later scholars, a flat heresy (al-Ghazālī

16 After al-Ghazālī, Sufi-Ash'`arī commentaries on the names including Abū Bakr. b. al-'Arabī, Ibn Barrajān, al-Qurțubī, and Ibn al-Uqlīshī tend to engage a longer list of names. These authors also ordered them differently. For instance, Ibn al-Uqlïshi's commentary is alphabetically arranged; Abu Bakr b. al-'Arabī's is ordered hierarchically according to the name's proximity to God; Ibn Barrajān groups his names into theological categories; and al-Tilimsānīs follows the names as they appear in the Qur'ān. 
1971, 42-43). In responding to the early Mu'tazili debates with Ahl al-Hadith, the succeeding Ash'arī scholars such as Ibn Fūrak (d. 406/1015), al-Qushayrī, and al-Baghawī (d. 516/1122), side with the Ahl al-Hadīth in affirming that the name is identical to the named. That is, the name is what is intended by the verbal utterance (al-muräd bi-l-lafz). They affirm an identity relation between God and His names in order to avoid the implication that the Qurān is created. In effect, they collapse the name (ism) and the named (musammā), and refuse to identify the names of God with mere temporally originated vocables (sing. lafz). ${ }^{17}$

Departing from the classical Ash'arī position over the identification of the name and the named, al-Ghazāli affirms the position that the name and the named are distinct. He sides with theological outliers-Mu'tazilīs and Ibn Hazm (d. 456/1064) whom he mentions in the Maqșad — but is followed by many late Ash'arī thinkers including al-Rāzī (d. ca. 544/1210) in his commentary al-Lawāmic (Gimaret 1988, 27-30; al-Rāzì 1905, 21-28). Al-Ghazālī affirms that the name, the named, and the act of naming are three distinct things (umür mutabayina), unless the "name" is loosely employed to denote the meaning of the name; and the thing named is its essence or quiddity (mähiyya). He explains that words that human beings employ to signify various entities may vary according to time and convention, whereas the existence of those entities-in-themselves ( $a^{c} y \bar{a} n$ ), and how they are experienced and conceptualised within the human mind remains the same (Kukkonen 2010, 68).

Just as the ma'na of a thing is an object of knowledge (malüm) whose reality resides in the thing-in-itself ('ayn), the ma'nā of God's name resides in God's very entity ('ayn); His Essence. This ma'nā is the eternal (qadīm) origin (așl) of the name, or an attribute (sifa) of God. The Qur'ann twice criticises idolaters for worshipping nothing but names that they have named (Q 12:40; 53:23). For idols have names (ism); names that possess no reality (musammāa). They are unreal (bātill) since there is no ma'nā within the idols' entities ( $\left.a^{\prime} y \bar{a} n\right)$. In contrast to empty names of idols, the most beautiful names of God (ism) convey

17 Later Sunnī traditionists, such as Ibn Taymiyya and his followers, contend that a name is for, or belongs to, the named (al-ism lil-musammā), as per the Qur'ānic verse to God belong the most beautiful names ( $\mathrm{Q}$ 7:180). According to this position, a name is not the named, but it conveys the named. The mystic Ibn 'Arabi's position in this semantic debate, however, is that the name is identical with the named if by "name" we mean the primordial eternal names that have no qualification nor etymological derivation. That is, the name of the name. But if we mean the names that are contained in human language, then they are other than the named. Ibn al-Arabī's solution to the problem of the name and the named is thus to affirm both the Ash'arī and the Mu'tazili positions at different ontological levels (Ibn 'Arabī 2010, 10). 
the knowledge that humans can grasp through the human mind (dhihn) about the named (macüm) realities in divinis. Being a mental form of cognition, this knowledge is a non-eternal (ḥa adith) form (șüra) of the eternal ma'ānì in God. For instance, the uttered expression, "the Merciful" (al-Rahìm) is an indicative signifier (dalīl) of what humans can grasp and vocalise (lafz) on the tongue (lisān) about the ma'nā of mercy in the Essence.

However, al-Ghazālī's semantics also affirms the early Ash'arī position to a certain extent. For these non-eternal names that are inspired on the tongues of humans and affirmed in scripture were also known by God in pre-eternity. Gesturing to the early Ash'ari identification of the name and the named, al-Ghazāli affirms that while the names are non-eternal because they are uttered, they are also pre-eternal ( $a z a l \bar{l})$ in the sense that they pre-exist in God's knowledge prior to their manifestation. The names were hidden in the world of non-manifestation (buțūn) or in potential (bi-l-quwwa). Even names like the Creator (al-Khāliq) are pre-eternal in potential (azalī bi-l-quwwa) prior to creation (al-Ghazālī 1971, 30-32).

By appealing to his semantic concept of macāni as immutable realities, transcendent attributes, or ineffable meanings of the Essence in pre-eternity (thābita fì l-azal), al-Ghazāin anticipates the classical Ash'arī criticism of his position. He affirms that the eternal ma'äni precede the non-eternal designations of those $m a^{c} \bar{a} n \bar{\imath}$ on the tongue, through the Arabic language, in the form of the divine names (al-Ghazāli 1971, 30-31). Yet the "names of the names" exist in pre-eternity in God's knowledge prior to the names. Thus, God was all-holy and all-knowing in pre-eternity before He took on or was worshipped through the names the All-Holy (al-Quddūs) and the All-Knowing (al-Alìm). The now created names al-Quddūs and al-Alimm were known to Him "in potential" in the world of non-manifestation (buțūn).

Al-Ghazālì's semantics is already discussed in his "Intentions of the Philosophers" (Maqūṣid al-falāsifa). Moreover, as Kukkonen has shown (Kukkonen 2010), the semantics in the Maqșad bears traces of the Peri hermeneias and Organon tradition, mediated through al-Farābī (d. 339/950) and Avicenna's (d. 427/1037) philosophies of language. His semantic discussion on what it means to assign a name (ism) to a thing (shay') is built on the Graeco-Arabic Peri hermeneias tradition, and al-Farābī's commentary on Aristotle's theory of signification is treated as a theoretical problem in Peripatetic Avicennan fashion.

But how does his Avicennan-inspired semantic position have traction in al-Ghazâli's commentary on the names? The answer lies in the ethical aims of his treatise. Al-Ghazāli enters into the age-old debate over the theory of signification with not only a new philosophical toolkit, but a different agenda 
in mind. He echoes al-Tabarîs complaint about the futility of this debate, but delves into the discussion with an aim to establish a semantic principle that creates theological stability for his ethical theory of takhalluq. To be clear: al-Ghazālì's Avicennan-informed semantics that posits a difference between the divine name and the named reality reinforces his insistence on transcendentalism and incomparability of the ma'ān $\bar{\imath}$ of God's names, or the "divine character traits" ( $a k h l \bar{a} q)$ even as he affirms the ability of the human servant to acquire those traits to a certain extent. The ma'än $\bar{\imath}$ of the divine names, or the character traits of God, correspond to the universals in divinity (al-ma'āni $a l$-ula of Avicenna), while the character traits (akhläq) acquired by perfected human souls are the particulars. Al-Ghazālì's semantics provide the theological foundations for his claim that humans can acquire virtue and ethical guidance in light of the names without running the risk of theological immanentism (tashbih) because it enables him to draw a line between the higher and inexpressible metaphysical ma'nā in divinis and the divine name which actualises that ma'nā in the believer on the mental and ethical planes. Al-Ghazālìs semantics thus affirm the sublimity of the names on the one hand, and the imperfection and non-eternity of human embodiment of those ma'āni on the other. This point will be explored further below.

\subsection{The Non-Synonymity (Man' al-Tarāduf) and Monosemy of the Divine Names}

Following his semantic discussion about the distinction between the named and the name, al-Ghazāli introduces two hermeneutical principles that complement his semantics and undergird his theory of takhalluq. He insists, first, that the divine names by definition are not synonymous, and second, that each name carries one single overarching meaning in divinis. That is, each name has only one, distinct meaning that it does not share with others regardless of how close the names may appear.

Al-Ghazāli discusses non-synonymity in Chapter Two of the Maqșad, and proclaims it to be an unprecedented hermeneutical move. This principle of non-synonymity is an offshoot of his semantic theory and is premised on there being ninety-nine "official" and exclusive names of God. However, al-Ghazālī later admits that pinpointing all the names scripturally is a task that poses many challenges. He contends nonetheless that a divine name by definition, or by virtue of being among the "official" ninety-nine names, must have one overarching ma'nā. Names are not divine by virtue of their consonants (hurūf) or the way they are articulated in the throat (makhärij). According to al-Ghazālì's line of thinking, synonymity among the names makes no sense. For if two names were to share the same meaning, then (1) either one of them 
is not on the list; ${ }^{18}$ or (2) commentators have failed to show different meanings of names, instead only underscoring differences in emphasis and scope. ${ }^{19}$

Al-Ghazālī accepts affinity (tanāsub) among the names, but not synonymity (tarāduf), and he holds that most mistakes and confusions in the divine names tradition arise from the failure of commentators to distinguish between the meanings (ma'annī) of the equivocal names (al-asmä al-mushtaraka). The names, he contends, may share qualities-e.g., the quality of majesty is common to the Great (al-Kabir), the Exalted (al-'Alī), and the Supreme (al-'Azim ) but there are significant modal differences between these names. Furthermore, differences between the names are sometimes due to differences in scope. For instance, the Independent (al-Ghanī) is subsumed under the King (al-Malik) since all kings are independent, but not all independents are kings. This principle, to al-Ghazāli's mind, acts as a deterrent against theological and ethical ambiguity. Moreover, it is theologically substantiated by a concluding chapter in the Maqșad where he demonstrates how each name traces back to the Essence through one of the seven essential attributes (al-Ghazālī 1971, 172-74).

The principle of non-synonymity moulds the Maqsad in creative ways. In order to adhere to this principle, he either appeals to names' contextual usage in the Qurān, emphasises morphological (șarf) distinctions, or assigns names to specific cosmological levels. He appeals to Qurānic context, for instance, when he engages with two pairs of contrary names: the Exalter and the Abaser (al-Muizz, al-Mudhill) on the one hand, and the Lowerer and the Uplifter (al-Khäfid, al-Rāfi) on the other. In order to distinguish between these two pairs of names, al-Ghazāli highlights that the Exalter and the Abaser are used in the Qurān (Q 3:26) to refer specifically to the giving or taking away of sovereign ownership, in contrast to the Lowerer and the Uplifter which refer to eschatological felicity and wretchedness, or proximity and distance from God (al-Ghazālī 1971, 94-95). Al-Ghazālī also appeals to morphological differences between the names to highlight the subtle but meaningful distinctions between divine names that share the same triconsonantal root, such as the names of concealment and forgiveness, al-Ghäfir, al-Ghafür, al-Ghaffär (Gh-F-R). ${ }^{20}$ As for employing cosmology, al-Ghazālī rejects synonymity among names that refer to God's creation and devising $(i k h t i r \bar{a})$, including the Creator (al-Khāliq), the Maker (al-Bāri'), and the Form-Giver (al-Mușawwir). He places

\footnotetext{
18 E.g. al-Ahad, the Only, is not included in Abū Hurayra's list, because al-A had and al-Wāhid, the One, denote divine oneness (tawhìd).

19 E.g., al-Ghāfir, al-Ghafür, al-Ghaffār (al-Ghazālī 1971, 36).

20 Al-Ghazālī points out differences in meaning between al-Ghäfir (root of concealment of sin, maghfira), al-Ghafür (intensity of concealment of many types of sin), and al-Ghaffär (the repeated concealment of sin) (al-Ghazālī 1971, 41).
} 
each name at a distinct cosmogonic level: (1) the Creator measures out and determines all things (taqdīr), (2) the Maker brings things forth from nonexistence to existence (ikhräj min al-'adam ilä l-wujüd), and (3) the Form-Giver imparts each existent thing its unique form $($ tașwìr $){ }^{21}$

In Chapter Three, al-Ghazālī drives his point home by insisting that each name carries only one meaning. The names are "most beautiful," for each carries a meaning of perfection, mercy, glory, grandeur, or eternity that befits it. Pushing against al-Shāfi'ì's position in $a l-U s ̦ u ̈ l$, he appeals to early Arab conventions of speech to make his case. For instance, when Arabs use a polysemic word like 'ayn (spring-source, essential identity, eye, etc.), they intend one of its dozens of meanings, not all of them at once. Al-Ghazāli objects to the position adopted by most commentators who take a name to mean multiple things, to have many ma'ānī, as long as those ma'āni are not rationally or theologically problematic. He ignores scholarly debates over the "differences of meaning" (ikhtiläffì l-ma'nāa), and in contrast to al-Qushayrī, al-Ghazālī tends to provide narrower and monosemic definitions of names.

However, there are passages in the Maqșad where morphology, Qurānic context, or cosmology do not lend themselves to al-Ghazālì's principle of nonsynonymity. This is the case for groups of divine names that are close in meaning yet do not share the same root. These include names of divine majesty such as the Tremendous (al-Azim ), the Majestic (al-jalil), and the Great (al-Kabir). In this case, al-Ghazālī finds creative ways of defining each in light of the other. However, these names are also more complicated because they tend to lend themselves to multiple definitions. Al-Ghazāli's most common hermeneutical move in such cases is to find a way of amalgamating the various meanings into one compounded concept. It should be noted that there are tensions between al-Ghazâlī's monosemic interpretation of names of majesty and the way they are used in the Qurān. For instance, the name al-Hakam is Qurānically associated with divine judgment, whereas in al-Ghazâlì's commentary it is associated with God's meticulous perfection of the cosmos. ${ }^{22}$

When al-Ghazālì comments on a name that has a plurality of ma'ānì, e.g. al-Saläm - which denotes both God's freedom from flaws and the safety of creatures by Him and through Him — he exerts independent thinking (ijtihād) to determine (ta'yin) the most appropriate meaning for this name and weaves both meanings brilliantly into a single constructed concept (al-Ghazālī 1971,

21 See also al-Ghazāli’s discussion of the difference in meaning between the Firm (al-Matīn) which denotes intense power (shadīd al-quwwa) and the Strong (al-Qawī) which denotes complete power (qudra tāmma) (al-Ghazālī 1971, 140).

22 I am grateful to my student, Ashhar Malik, for this insight. 
73). In a similar move, the Guardian (al-Muhaymin) is a name that combines the meanings of God's overseeing (ishräf), which is a quality of divine knowledge, as well as dominance (istil $\left.\vec{a}^{3}\right)$, which is a quality of divine power, and finally preservation, (hifz) which is an act of God $\left(f_{i} i\right)$. The three meanings come together in this name (al-Ghazālī 1971, 76). ${ }^{23} \mathrm{Al}$-Ghazālì's discussion of the name al-'Azizz is also noteworthy (al-Ghazāli 1971, 77). Most commentators proclaim this name to be inherently polysemic. Its meanings include the Mighty, the Exalted, the Precious, or the Inaccessible, and each meaning has ethical and theological connotations. In the Maqșad, al-Ghazāli concedes that al-Aziz carries three meanings, but he insists that these merge together to form a single meaning. ${ }^{24}$

In addition to amalgamating various meanings into one compound meaning, al-Ghazâli's hermeneutics is also guided by what he considers to be the most theologically fitting meaning of a polysemic name. For instance, the name al-Mu'min means the Provider of Safety ( $a m n)$ as well as the Affirmer (tașdiq). However, affirmative belief (tașdi $q$ ) is a more fitting quality of human beings, whereas providing safety is God's. Thus, al-Mu'min is defined as Provider of Safety. In other cases, such as the Guardian (al-Muhaymin) and the Watchful (al-Raqīb), he works by elimination and reasons that al-Muhaymin should exclude the meaning of watchfulness. In such cases, the names operate intertextually and explain each other, just as Qurān commentators use the Qurān to explain itself.

Sometimes, it is clear that al-Ghazāli is unable crack the puzzle. He fails to come up with a creative semantic amalgamate for certain names. His theologically-driven semantics are disrupted by the Qurān's polysemic usage of the names. In these occasions, which are impressively rare, and in which polysemy is indisputable, al-Ghazālì points to the two irreconcilable meanings and moves on. Thus in commenting on al-Muqit, which means the Overpowering (Q 4:85) as well as the Nourisher, al-Ghazālī seems to concede that the name has two have very distinct meanings that cannot be combined. His theory of monosemy does not always work, and Qur'ānic verses confirm this (al-Ghazālī 1971, 123). ${ }^{25}$

Al-Ghazālì's drive for systematisation and his commitment to nonsynonymity and monosemy of the names makes the Maqșad a hermeneutically

23 Likewise, the name al-Lațîf, the Subtle, combines the meanings of kindness in action (al-rifqfíl-ficl) and subtle perception (al-lutffi l-idrāk).

24 See also his commentary on the Ruler, $a l-W a \bar{l} \bar{i}$, as an amalgamation of the meanings of governance (tadbir), power (qudra), an activity $\left(f^{i} l\right)$.

25 See also his discussion of the two meanings of the name al-Shahìd (al-Ghazāli 1971, 137). 
creative, albeit rigid text. While other authors celebrate polysemy and attempt to understand multiple valid interpretations of the divine names, al-Ghazāli establishes the ma'anni as eternal attributes in the Essence, then proceeds to argue that each of the ninety-nine scripturally affirmed divine names correspond to one single ma'na in divinis. Paradoxically, while al-Qushayrī holds the rigid position that the name and the named are identical, he has a more flexible and open-ended treatment of the names, and is receptive to a broader set of ethical possibilities for each of them. In contrast, al-Ghazālī insists that the eternal ma'na and the non-eternal name are distinct, yet he fences each name semantically and limits its theological and ethical ramifications. ${ }^{26}$

Despite his claims to its originality, al-Ghazālī's doctrine of non-synonymity also has its own long and complex genealogy. Historically, it was adopted by some Ash'arīs as an anti-Mu'tazilī move. For most Mu'tazilī theologians had argued that the multitude of names are reduced to mere redundancy. Accordingly, divine unity can only be secured if the names are collapsed onto the attributes, and the latter onto the attribute of knowledge ( $\mathrm{l} / \mathrm{m}$ ), which for its part stems from the Essence. Some went so far as to argue that the divine names are like frozen proper names (asmä al-a $\left.\bar{a}^{\prime} \bar{a} m\right)$ that denote the Essence but carry no meaning. An extreme — though non-Mu'tazilī — case appears to be Ibn Ḥazm, who, according to Ibn Taymiyya (d. $728 / 1328$ ), claimed that the divine names all correspond to proper names that do not carry any meaning (Ibn Taymiyya $1965,76-77) .{ }^{27}$ For al-Ghazālī, the names are both proper names (a'lām) in the sense that they denote the same Essence, yet they carry distinct meanings (awșăf) and specific denotations. The names are synonymous (mutarādifa) in respect of the Essence, since they denote a single divine reality; but they are distinct (mutabāyina) in respect of their specific attributes (Frank 1978, 55-56). Al-Ghazālī adopts this principle of non-synonymity and polysemy in light of his philosophically-informed semantics, and in an attempt to remove

26 There are certain exceptions in which al-Ghazāli’s monolithic interpretation of a divine name has a broader function than al-Qushayri's commentary, as is the case with the name the Concealing (al-Ghaffār).

27 Al-Ghazālī mentions in the Maqșad that Ibn Hazm is a hadìth scholar from the Maghrib who collected the names from the Qurān. The reference here is to al-Muhallā bi-l-äthār fi sharh al-mujallā bi-l-ikhtișār, as Ibn al-Uqlīshī explains (Ibn al-Uqlīshī 2017, 1:177). Ibn Hazm in the Muhallā maintains a strong tawqīf $\iota$ position, arguing that our knowledge of the divine names is conditional upon scripture, and that it is impermissible to call God except by what He calls himself (Mas'ala \#54, 57), that there are ninety-nine names only and no more; and that derivation (ishtiqāq) of the names is not permissible whatsoever. He lists 84 names from the Qur'àn, and describes the lists of the names in the hadīths as "shaky" (mudțarib). The names Ibn Hazm lists are found in Kitāb al-İșāl, and Ibn al-Uqlīshī lists them in his Inbä' (Ibn al-Uqlīshī 2017, 1:169-77). 
ambiguity from his commentary on the divine names. Each name has a clear and single meaning that corresponds to a single human ethical ideal. For him, ambiguity over the root of any name, even the name Allāh, or debates over the meanings of the name, destabilise and complicate his ethical project.

Al-Ghazālì's semantic theory dovetails with his concept of ma'nā. Indeed, the central concern of the Maqșad is expressed in its title: Al-Maqșad al-Asnā $f \grave{\imath}$ Sharh Ma'ānīal-Asmā' al-Husnā ("The Highest Aim in Explaining the Meanings of God's Most Beautiful Names"). The key term here is ma'nā (pl. ma'ānī), whose significance is evidenced by my lack of translation. It is often glossed as pure, transcendent, or supra-sensory meaning; concepts which describe it in contrast to a tangible or intelligible "form" (șurra). At the most basic level, a ma'na, or "meaning" refers to a thing that one intends to convey primarily through language. But the Arabic word that comes closest to this sense of the term ma'nā is al-murād, or "what is intended" by the speaker. In contrast to the speaker's intended meaning (al-murād), the ma'nā exists within an individual entity ( $f i l-a^{\prime} y \bar{a} n$ ). If it pertains to the sensory realm, then the ma'na of Zayd for instance inheres in Zayd. If it pertains to the intelligible realm, then it exists in the mind: my concept of Zayd has a ma'nā in my mind ( $f i l-d h i h n)$.

In theological terms, what al-Ghazāli means by ma'nā of a divine name is a unique, inexpressible, inaccessible, inexhaustible, unqualified, and eternal reality, trait, or attribute of God's Essence. Each divine name has a ma'nā to which it corresponds, which is to say that it has a reality within the unqualified Essence of God. These ma'āni are distinctions not divisions, differences not separations, in divinis. They are unique to God in their fullness and perfection. Being supra-formal, they are not observable and cannot be comprehended by the human intellect. The ma'na of the divine name in the human mind is incommensurably limited in relation to the mana $\bar{a}$ of that name in the Essence.

The chasm between the divine ma'nā in the Essence and human apprehension is usually described in the Maqșad as one that is absolute. Although knowledge of the meanings of the divine names is inferred from observing that this world necessitates a Creator who possesses essential attributes of life, knowledge, will, and power, these attributes that we grasp from empirical observation only hint at, yet do not truly correspond to God's actual qualities. To illustrate this chasm, al-Ghazālī compares the human attempt to grasp God's qualities to a prepubescent child's attempt at understanding the pleasures of the conjugal act. The best an adult can do to explain it is to compare it to the 
sweetness of sugar. Until the child attains puberty and experiences adult pleasure, he or she cannot know what it is in itself. Analogously, unless one is God, one cannot fully know Him, for there is no correspondence between God and other-than-God. Therefore, only God knows God (al-Ghazālī 1971, 162).

Al-Ghazālī thus affirms not only that the Essence is unknowable, but so are the attributes, or the ma'ānī. A ma'nā is God's exclusive possession and as such it is inconceivable in itself. Why are the ma'añ inexhaustible and incomprehensible? To answer this question, al-Ghazāli typically points to the "names of divine acts" (sing. ism $f i l$ ) such as the Creator (al-Khäliq). This name encompasses all of existence, for God's acts engulf all knowledge. A name like the Determiner (al-Hakam) or the Equitable ( $a l-A d l)$ would exhaust all sciences of humankind ('ulüm) to be thoroughly explained. The reality of the name the Creator is only known by the one who knows the reality of divine acts $\left(a f^{\prime} \bar{a} l\right)$. This name of act can be known in summary (bi-l-jumla) not in detail (bi-l-tafșill) and not in an exhaustive manner (bi-l-hașr). Other names of act, like al-Bä'ith, the Resurrector, are in the realm of the unseen and will only be fully disclosed on the Day of Resurrection (al-Ghazāli 1971, 133). Due to their incommensurability, al-Ghazāli endorses the Ash'arī position that our knowledge of the divine names is conditional upon revelation. They cannot be rationally inferred, and we must call God by what He calls Himself (tawqïf) in scripture. For by naming God on the basis of reason, the caller inevitably commits tashbih by projecting human states and anthropomorphic assumptions onto Him. ${ }^{28}$

28 The Ash'arī doctrine of tawqīf was articulated against the backdrop of internal Mu'tazili debates on whether the human intellect can assign names to God. The Bașran Mu'tazilīs held that the intellect can name Him, thus violating the principle of tawqĩ that the Baghdād school of Mu'tazilism adhered to (al-Ghuṣn 1996, 62). Imām al-Ash'arīs Bașran Mu'tazilī teacher al-Jubbā'ì (d. 303/916) held that if the intellect ('aql) deems a certain meaning $\left(m a^{\prime} n \bar{a}\right)$ to be admissible for God, then it is obligatory to name Him by that meaning, even if there is no revealed text to confirm it (al-Ash'arī 1969, 2:207-208). The Baghdād Mu'tazilīs differed with al-Jubbāì on this point. They insisted, for instance, that God called Himself al-'̄lim (The Knowing) not al-'Árif (The Recogniser) and that His self-designation should be respected. The doctrine of Tawqif was also articulated by the early Ahl al-Ḥadìth scholars. For instance, al-Khațāaī (d. 388/998) held that one must describe, name, and affirm God in His incommensurable beauty and perfection just as $\mathrm{He}$ describes, names, and affirms Himself, not through the intellect (al-Ghuṣn 1996, 47). For instance, one should not call God the Eternal (al-Qadim) or the Essence (al-Dhāt) since He does not call Himself that. Likewise, one should not name God on the basis of synonymous terms established by scriptural names or by linguistic analogy (qiyās lughawī). For instance, God cannot be called Teacher (múallim). In similar vein, the Ash'arīs in general adhered to the principle of tawqīf. They maintain that the process of ascribing names to the divine Essence must be moderated by scripture, for naming God is an act that pertains to the unseen realm and therefore must be conditioned by the Qur'ān and Prophetic 
It is interesting to note, however, that al-Ghazālī sometimes softens his tone and describes the chasm that separates the name's $m a^{\prime} n \bar{a}$-in-itself from human apprehension thereof in terms of degree. For instance, he says that our apprehension is to the divine mána as a ray is to the sun. (al-Ghazāli 1971, 58-59). The reason for this concession is that we attempt to know God by comparing His perfect attributes to our limited ones; we allude to His meanings by suggestive comparison (īhäm) to our attributes that we "share" with Him. And in the end, we can only understand God in terms that are familiar to us, or that have a correspondence in us. We only truly recognise ourselves, and can only relate to God by a suggestive analogical comparison. The fundamental flaw of that comparison, moreover, is affirmed by the Qurānic verse: nothing is as His like (Q 42:11). This principle of non-analogy, moreover, applies to everything that is unseen in relation to us, including our knowledge of prophecy, heaven, and hell-hence Qurānic descriptions of the afterlife in this-worldly terms.

Anthropopathism

A discussion of al-Ghazāli's treatment of tashbīh is in order. For in expounding upon the ma'ān̄̄ of the divine names and their ethical significance, al-Ghazāli is anxious not to be misunderstood as promoting any kind of theological immanentism (tashbih). The heretical immanentist doctrines that he was particularly concerned about include mystical proclamations of unificationism (ittihāad) attributed to extreme Sufis, doctrines of indwelling (hulūl) ascribed to Christian Trinitarian theology, and the overly literal and crude anthropomorphism (tajsīm) of the Karrāmīs, extreme Ḥanbalīs, and the Zāhirīs who ascribe human physicality to God. He thus dedicates a separate section of the Maqsad to refute these forms of immanentism, ${ }^{29}$ and calls attention to the dangers of

Tradition. The Ash'arīs therefore "stop" at the names found in scripture. Al-Ghazālī agrees that the final arbitrator in naming God is the soundness of the transmission of the revealed text. In this spirit, al-Ghazāli holds that it is not permissible to extract divine names from Qurānic verbs ascribed to God, despite the fact that divine names stem from verbs (al-Ghazālī 1971, 165).

29 Following his introductory chapters on theology, semantics, and takhalluq, al-Ghazālī includes an apologetic concluding section following his commentary on the ninety-nine names to refute immanentist heresies of transferal (intiqāl), unificationism (ittihāad), indwelling $(h u l \bar{u} l)$, and characterising oneself by the actual attributes of God (al-takhalluq bi-'ayn al-șifät), and he proclaims that his orthodox position is the "assumption of the likenesses of the attributes of God" (al-takhalluq bi-mithlihā) which affirms a correspondence between divine and human attributes in a broad sense (munāsaba 'alā al-jumla) 
tashbīh (hashwiyya, mujassima) in several entries in the Maqșad (al-Ghazālī $1971,115-118){ }^{30}$

However, beyond God's non-spatiality and non-corporeality, al-Ghazālī is also attentive to a subtle and pervasive form of tashbiht the ascription of human emotional and psychological states to God. "Anthropopathism" is a theological deviation that has no name in the Maqsad, yet it plays a key role in how al-Ghazālī frames each entry within an Ash'arī volitionist perspective, and it sets the stage for the names' ethical applicability. For if we were to conceive of God's mercy as being similar to human mercy, then this would entail that God experiences feelings of hurt when He punishes servants, or that He suffers when a servant disbelieves in Him. It would entail that He experiences relief when showing mercy. For Ash'arīs, God experiences neither pleasure nor pain, and His actions are not motivated by them. His mercy and wrath do not work in a human way. Mercy is His will to benefit and bless the servant, and anger is His will to punish.

Thus, names of positive emotion such as mercy, denote God's “will” or choice to save, whereas names of negative emotion such as anger denote His "will" to punish. Names that hint at an emotional correspondence between servant and Lord are metaphors ( majāz) for various aspects of God's will. Al-Ghazāli’s commentary on the Ever-Merciful (al-Rahim) illustrates this balance, and is key to his theology since all positive names are included within Mercy, which is included within the divine will. He upholds Ash'arī volitionism, and insists that divine mercy does not entail that He is emotionally invested in the wellbeing of His servants. On the name the Loving-Kind ( $a$-Wadūd) he says:

Just as His mercy means that He wills the good for His object of mercy, and that He gives him all that he needs while being free from the binding empathy that is [commonly associated with human] mercy, so His intense love (wudd) is His will to honor and bless, as well as His beneficence (ihssān) and favor (in'äm). Yet He is free from the natural inclination [that is commonly associated with human] love and mercy. For He only wills love and mercy for the sake of their fruits and benefits, and $\mathrm{He}$ is not [motivated by] binding empathy and inclination. For benefit is the very kernel of mercy and love; it is their spirit. This is what should be

not in the full sense of the term (mumāthala tämma), and a sharing of common names (mushāraka fì l-ism) (al-Ghazālī 1971, 163-71).

30 He calls attention to the dangers of corporealism when discussing names like Al-Samī, the Hearing, and al-Bașir. For instance, the Seeing is easily prone to anthropomorphic interpretations (tashbïh). There is mumäthala: we hear and see, as does God; but we can only conceive of sight through our limited faculty of vision. 
conceptualized in the case of God's [mercy and love], glorified and exalted, setting aside all aspects associated [with human experience] and which are not a condition for bestowing benefit [in the first place].

AL-GHAZĀLī 1971, 132; English trans., 119

At first blush, this cold Ash'arī language seems to strip God of all positive attributes. Indeed, Ibn Taymiyya criticised the Maqșad on this very point, accusing al-Ghazālì of denying the attributes (see below). For al-Ghazâlī, the Ash'arī framework is not reductionist, but rather enables a non-literal yet faithful interpretation of anthropopathic names and verses of the Qurān and the Prophetic Tradition. In al-Ghazālī's way of looking at things, this volitionist language does not deny God's attributes due to their perceived imperfection. Rather, volitionism affirms that His attributes are so perfect that they are absolutely distinct from human traits. That is, although stripping mercy of its anthropopathic and emotional connotations seems excessively transcendentalist, it is not a deficiency in the meaning of mercy. Rather it is a perfection, since perfection of mercy rests in the perfection of its result, and an emotionally invested Lord is a deficient one. What would God's emotional investment add to the $m a^{\prime} n \bar{a}$ of His mercy? An emotionally invested Lord seeks through His mercy to relieve His own pain and hurt, and is thus merciful for human "selfish" reasons. For al-Ghazālī, the perfection of divine mercy entails that $\mathrm{He}$ is merciful purely for the sake of His servant and that He is not motivated by self-relief. If God were emotionally and affectively invested in His relationship with humans, then His attributes of mercy, kindness, and love would be incomplete and transactional. It is for this reason that "God is hallowed beyond the sympathetic tenderness of mercy (riqqat al-rahma), and the affective inclination of mutual love (mayl al-mawadda)" (al-Ghazālī 1971, 132). He is the All-Holy ( $a l$-Quddūs), and therefore is hallowed beyond human imperfections, attributes, traits, feelings and psychological states.

Some divine names which have anthropopathic connotations are real with respect to the servant, and metaphorical with respect to God. These include names such as the Grateful (al-Shakür) and the Patient (al-Sabür). Human patience implies constraint and torment of the self, whereas divine patience is identified with God's will and power (qudra). That is, God's patience is His will to arrange all things according to their proper time (al-Ghazālī 1971, 84, 161). Hence there is no suffering (muqāsāt) of God doing something that is contrary to His will (irāda). He is not pulled in two directions so that He would have to resist or suffer from the pull, or desire for another action. His patience is His determination of all things in their appropriate preordained time (al-Ghazāli 1971, 161). God is the Forbearing (al-Halim), but does not react emotionally 
to human acts of disobedience (al-Ghazālī 1971, 112). Moreover, God's selfgreatness $(k i b r i y \bar{a})$ is a perfection of His existence (kamāl al-wujūd), not an emotional state, a display of arrogance, or a pretence of greatness; for God is too great to display pride vis-à-vis humans (al-Ghazālī 1971, 118).

The language that al-Ghazālì evokes to define and describe such divine names was refined over successive generations of Ash'arī theological reflection. ${ }^{31}$ Earlier Ash'arī figures, including the eponymous founder Imām al-Ash'arī (d. 324/936) and Ibn Fūrak (d. 406/1015), already laid the foundations for Ash'arī attitudes toward anthropopathism in their writings. These definitions were molded against the backdrop of Mu'tazili conceptions of divine will as God's approval, consent, and inclination. (van Ess 1997, 4:445-447). For the Ash'arīs, divine will itself is completely different from human will, and is defined as the function in God which chooses one thing over another (tamyiz al-shay' 'an mithlih) and as such is ultimately indistinguishable from the divine command (al-Ghazālī 2008, 173; al-Juwaynī 1950, 237-38). Al-Qushayrī also maintains this transcendentalism in this commentary on the names, and explains that the meaning (ma'na $)$ of mercy is God's will to bless His servants (irädat al-ni'ma); and that this "will to bless" is called "mercy" only metaphorically. ${ }^{32}$

So far, so transcendent. But how then does al-Ghazâlīs conception of an unknowable God really differ from that of the Mu'taziliss? If the discontinuity

31 For an excellent analysis of anthropopathism, to which this section of the paper is indebted, see Güleçyüz, Mütekaddimîn Dönemi Eş’arî Kelâmında Beşerî Duyguların Allah'a Nisbeti Meselesi. As Güleçyüz argues, an extreme transcendentalist position is adopted by al-Juwaynī in the Irshād, who reduces anthropopathic verses and traits to the transcendent will of God, and proclaims that God neither loves nor is loveable in the normal emotional sense. "When we say that God, exalted, loves a servant, we do not mean that He has affection (tahannun) and inclination toward (mayl) him. Similarly, the servant's love for His Lord is his submission and obedience to Him. For God is hallowed beyond inclining or being inclined toward" (al-Juwaynī 1950, 238). Thus, God is too transcendent to offer emotional affection, nor can He be the subject of human affection, since that would imply a dependency in God. Ash'arī Qur’ān commentators, such as al-Bayḍāwī (d. 685/1286), apply this theological principle to their exegetical approach to verses that ascribe humanlike emotional states to God, such as verses that speak of God as Lover: He loves them and they love Him (Q 5:54), or Prophetic Traditions that describe God as having jealousy.

32 Al-Qushayrī's commentary on the Loving-Kind ( $a$-Wadūd) is illustrative (al-Qushayrī 1986, 176). His loving kindness is His mercy, will, and praise of His servants. It may also be an attribute of act such as bestowal and excellence toward servants. In return, the servant's love is to remain steadfast in obedience. Al-Qushayrī then offers heartwarming anecdotes, and hyperliteral mystical interpretations of the roots of key words, to personalise the name al-Wadūd. Similarly, God's clemency ( $\left.r a^{\prime} f a\right)$ is intense mercy according to al-Qushayrī (al-Qushayrī 1986, 239). 
between God and creation is not absolute, what serves to bridge the disconnect? Al-Ghazālì's first step toward answering this question is to rationally refute $\mathrm{Mu}$ 'tazilī theological transcendentalism $\left(t a^{\prime} t \underline{t} \bar{l}\right)$ which affirms some attributes (Creator, Necessary Being) and the Jahmīs who purportedly deny all attributes. He thus devotes two chapters to critiquing of the negative theology of Mu'taziliss who deny the divine attributes $\left(t^{c} t \underline{t} \bar{l}\right)$ by collapsing them into the Essence; as well as Avicennan philosophy which reduces God to a philosophically abstract "creation machine" that believers cannot relate to ethically. ${ }^{33}$ Like other Ash'arī theologians, he describes this negative theology as a "heresy regarding God's names" (lit. "deviating in the names," al-ilhâad fi l-asmā', Q 7:180) since one is adding beyond what is permitted, or falling short of what is commanded. ${ }^{34}$

33 Al-Ghazâlī is so concerned about the risks of negative theology that after his commentary on the ninety-nine names, he devotes two chapters to the core Maqāsid wa-ghāyāt to explain how each name resolves to the seven attributes and the Essence according Ash'arism, and how all the divine names fall under ten categories. These chapters are similar to his discussion in the Ihyyā', Kitāb Qawā'id al-'Aqā̉id (al-Ghazālī 2011, 1:331-380) which begins with a basic Ash'arī creedal proclamation for children, explaining the two shahädas in terms of the seven essential attributes and the basics of prophecy. Moreover, in the Ihyā', from al-Risāla al-Qudsiyya (al-Ghazālī 2011, 1:381-424) onward, there is an expansion on his creed. He discusses qualities of the divine Essence, attributes, acts, eschatology, as well as political leadership and the status of the companions, and the text is framed against the Mu'taziliss and Shììs. He divides names into those that denote the Essence alone, such as Allāh; or names that denote the Essence with negation, such as the Independent ( $a l$-Ghani $)$; names that resolve to the Essence with a relationality, such as the Exalted; names that resolve to the Will with a relationality or an act, such as the All-Merciful (al-Raḥmān), or the Loving-Kind ( $a l-W a d \bar{u} d)$, for according to Ash'arī volitionist theology divine mercy stems from will and God's excellence and bounty.

34 These two chapters of the Maqșad are reminiscent of al-Ghazālī's Chapter Six from the Tahäfut al-Faläsifa, in which he refutes the philosophical and Mu'tazilì doctrine of the attributes. A similar discussion is found in al-Iqtișād fí l-I'qitād. In the second quțb of the Maqșad, al-Ghazālì discusses the properties (ahkām) and dictates (lawäzim) of the attributes. After a description of the Mu'tazili position, he refers the reader to his refutation in the Tahäfut. He adds with hesitation: "should anyone wish that it not be included in this book, he may drop it, since it is of no importance to the [argument] of the book." This chapter is followed by a discussion of how the philosophers and Mu'tazilīs reduce all the attributes to divine knowledge ( ${ }^{\circ} \mathrm{l} / \mathrm{m}$ ), which is reduced to the Essence. They claim that the attributes coincide with the single Essence of God, thereby denying the attributes (tațîl) and claiming that they cannot be fathomed by the intellect (al-Ghazālī 1971, 139). All names contain an attribute; but not all attributes comprise a name (e.g. Hand, Eye, Speech). Al-Ghazāli also refutes Avicennan philosophy of emanation and eternity of the universe, which also reduces God to an eternal, impersonal, philosophical abstract that functions as an emanative "creation machine." 
Aside from refuting extreme transcendentalism, al-Ghazālì's constructive answer lies in the fact that God describes Himself to us and in relation to what we can possibly understand about Him. God crosses the chasm by addressing us so that we may cross back to Him. He describes Himself through forms (sing. șüra) that exist in our limited minds, in the sensory domain, and in the literal meanings of human language. These pale reflections of the eternal ma'anni initiate the servant's process of internalising those names according to his own measure, by grasping their meanings intellectually and inculcating some of their ethical consequences existentially. As it turns out, the ma'nā is not completely inaccessible. It faces both directions: the Essence and the name. The name, for its part, points to the servant's limited ability and the ma'nā. Thus, the divine names bridge an otherwise inaccessible and incomprehensible ma'nā within the Essence because they are addressed to our understanding. They communicate the ma'na through human speech and human proportions.

A divine name thus denotes a certain property, characteristic, and quality of the Essence that we cannot fully fathom. What we glean from a name is in relation to us. Our understanding thus confines the ma'nā, by setting a subjective and linguistic prism around it. The ma'n $\bar{a}$ is an interface between the unqualified Essence and the qualified divine names $(a s m \bar{a})$. Consequently, the names are an interface between the perfect ma'ann $\overline{~ o f ~ t h e ~ E s s e n c e ~ a n d ~ t h e ~ i m-~}$ perfect human grasp of those ma'anni in the mind. For it is precisely because the inexhaustible ma'ān $\bar{\imath}$ can be communicated to a certain extent through scriptural reference that they can be put into practice to some extent. Al-Ghazālì's Highest Aim is thus to shed whatever light possible on the ultimately unfathomable ma'na of each name, or the realities of the names in God, guided by theological reflection and linguistic exposition. The ultimacy of the man' $\bar{a}$ is communicated through the intelligibility of the divine names, which is internalised through the intimacy of spiritual practice and cultivation of virtue. This is where takhalluq starts.

The theory of takhalluq allows al-Ghazāli to switch perspective by contemplating the relationship between the Creator and the created from the human standpoint. Turning his theological gaze to the field of ethics, he notes that since the names are divinely intended to generate some kind of understanding of the ma'āni in human language, they cannot be completely incomprehensible. The theological sublimity and ultimacy of the ma'ān $\bar{\imath}$ must not render 
God's attributes inoperable ( $\left.t a^{\prime} t t^{\prime} l\right)$, but rather should communicate an archetypal code of ethics for human conduct. The ma'anni can be experienced and enacted to the extent of the observer's own measure.

To this effect, al-Ghazāli affirms that ethics can neither derive directly from God who is incomparable, yet nothing else can serve as the ultimate prototype for human comportment and virtue. Thus, instead of asking "what right do humans have to assume divine character traits?" he insists that there must be a relationship between God and human ethics. For within a world governed by divine oneness (tawhìd), if human ethics are not somehow divinely prefigured, what else could serve as prototype for human comportment? If all human beings were born prelingually deaf, would God describe Himself to us

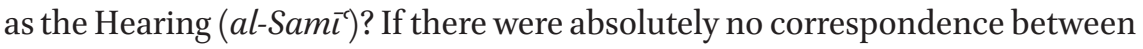
the human grasp of the meanings of the names, then what meaning would Qur'ānic descriptions of God have? Al-Ghazālī thus makes a case for the possibility of characterising oneself by the transcendent meanings of the names at three different stages of grace. These stages, or the "shares" (sing. hazz) in the names, determine the servant's proximity to the angelic state and to God. Ascending through these stages presuppose a demonstrative unveiling of the ma'ān in the intellect, a reverence and attraction to them in the heart, and purification of the soul. In contrast to al-Qushayrī, al-Ghazāli insists repeatedly that the Prophets and Messengers embodied these three levels to the fullest extent (Chiabotti 2017, 189). But how?

\subsection{First Share: "Demonstrative Unveiling" (Inkishāf Burhānī)}

Al-Ghazâli insists that the human being can potentially reach a "share" ( $h a z z)$ in all the divine names. This human "share" (hazz) goes beyond "hearing" the name, for even the eardrum of a dumb beast can capture soundwaves. It also surpasses comprehension of the linguistic meaning of a name, for any simple Arab Bedouin understands the surface meanings of the ninety-nine names. This "share," moreover, surpasses abstract belief in the heart, for any common believer or child has abstract belief. Common believers and exoteric scholars ( $\left.u l a m a a^{\prime}\right)$ tend to know the names merely at the level of the uttered sound (lafz), philological meaning (lugha), and abstract belief in the heart (al-Ghazālī 1971, $42-43)$.

In contrast, the advanced seeker recognises the divine names in three ways. The first is unveiling (mukhāshafa) and direct witnessing (mushähada) of the meanings of the names such that their realities become demonstrably clear. At this level, the fact that God is qualified by His meanings is grasped with the same degree of certainty that one has of one's own inner attributes, attributes 
of the self which we perceive not through outer sensory perception but the witnessing of our inner senses. This demonstrative unveiling is captured by his discussion of the names the Manifest (al-Zähir) and the Non-manifest (al-Bāțin). God is the Manifest (al-Zāhir) by way of demonstrative proof (istidläl), since we can prove God's existence cosmologically and teleologically. Yet He is the Non-manifest (al-Bățin) in relation to our senses, for everything points to Him and there is no way to contrast an existent thing that points to God from one that is completely devoid of divine signification. Thus, God is so manifest that He is non-manifest, and if something did not point to Him it would be possible to understand how the rest points to Him. (al-Ghazāli 1971, 147-149). This point about God's manifestness and non-manifestness, according to al-Ghazālī, is grasped through contemplative study that leads to "demonstrative unveiling."

There is thus a strong rational streak to al-Ghazāli's discourse on direct taste, or the fruitional experience of Sufis (dhawq). In effect, al-Ghazālī applies the Aristotelian methods of demonstration that are employed in the works of Avicenna to Sufi discourse on unveiling. As such, the indubitable standards of demonstration of falsafa apply to the Sufi "science of unveiling" ( ilm al-mukāshafa), such that the unveiled person has an ineluctable certainty about God's assumption of the eternal traits that is as self-evident as his own assumption of human virtues. In al-Ghazālī's Maqșad, Avicennan burhān is mysticised, and mysticism is Avicennised in this process of "demonstrative unveiling" (inkishāf burhānī) (al-Ghazālī 1971, 54-55). For in contrast to Latin logic, al-Ghazāli's burhān is the highest form of conveying truth and a demonstrative knowledge that brings with it ineluctable intellectual and illuminative certitude.

Al-Ghazālì's idea that the direct recognition (márifa) of the meanings of the names by way of unveiling (mukäshafa) and witnessing (mushähada) operates through a demonstrative knowledge (burhān) that does not allow for error (al-burhān al-ladhì là yajüz fihhi l-khața') stands in contrast to the notion of mystical knowledge (ma'rifa) in other schools of Sufism. In the school of Ibn 'Arabī, for instance, ma'rifa is understood as the beginning of the obliteration of the servant's trace (mahw al-rasm). It is where the line of demarcation between divine and human traits begin to blur, and the beginning of annihilation. To realise a name is to obliterate an aspect of one's self. In the Maqsad, this anarchic moment is never entertained: the lines between servant and Lord are never complicated. 


\subsection{Second Share: Reverence, Attraction, and Self-Purification}

When the divine attributes become demonstrably unveiled in their full glory, the heart naturally begins to become imbued with reverence for them (isti'zamm). At this level, the servant is characterised by a longing for the names and an incitement to ( $\left.b \bar{a}^{c} i t h\right)$ adorn himself by their qualities in any way possible. This incitement in the heart marks the beginning of the servant's journey toward proximity (qurb) to the Real. This process, however, cannot begin if a heart is stirred up for anything other than God. For just as a student in a state of hunger cannot acquire knowledge until he is satiated, or just as a teacher cannot be fully present in delivering his morning lecture until he has had his cup of coffee (not al-Ghazālī's metaphor), a heart cannot have complete longing for God until it has emptied itself of worldly desires and attachments. Hence the indispensability of renunciation and inner purification in the process of refining the soul and transforming character (al-Ghazālī 1971, 43-44).

A soul that is purified begins to realise its servanthood and need for God. It gains its first glimpse at its "share" in some of the ma'āni of God's names or character traits $(a k h l \bar{a} q)$. It begins to adorn itself with God's seven essential attributes - Life, Knowledge, Will, Power, Hearing, Seeing, and Speech — which are innately imprinted upon the canvas of the human soul. For the human soul is created in God's form (șüra), and virtue pre-exists in the innate human disposition ( fitra). However, God lives, knows, wills, and exerts power by and through Himself; whereas the servants' traits are sustained through God's selfsustenance. Moreover, God's akhlāq, or the ma'ānī, reside in His Essence, while human character traits reside in the heart. Divine akhlāq manifest in God's acts $\left(a f^{\prime} \bar{a} l\right)$ - i.e., the cosmos $(k a w n)$ - or the effects and traces ( $\bar{a}$ thār $)$ of His names and attributes. Human virtues manifest on the bodily limbs through human actions ( $\left.a^{\prime} m \bar{a} l\right)$ and interactions (mu'āmalāt).

God's essential traits are nondelimited, whereas human traits are delimited. God's $a k h l a \bar{q}$ are perfect and not subject to change, while human virtue is intrinsic to the human state, but can become debased to the predatory (sabu $\bar{\imath})$, beastly (bahimmì), or satanic (shaytānn̄i) states through indulging in vices and worldliness. Human traits must become refined (tahdhïb al-akhläq) as the human being reclaims his innate disposition ( fitra) and approaches God's perfections and through spiritual exercise (tarbiya), adherence to the Sharía, performance of supererogatory devotions, acquiring and applying knowledge, and seeking righteous company.

The process of takhalluq, or the "assumption of divine character traits," is at once a movement toward the human innate disposition ( fitra), a movement toward God, and an affirmation of the correspondence (munāsaba) between God and the human being. It is in light of this correspondence that God 
ascribes the human spirit ( $r u \bar{h} h$ ) to Himself, teaches Adam all the names, allows him to speak about what can be named (including God), commands the angels to prostrate to him (and to God), and appoints Adam and his children as His vicegerents on earth (khalifa). This status of vicegerency is also why Adam's children are given the power to represent God's beauty and splendour, or, alas, to destroy themselves and the earth $(\mathrm{Q} 2: 30-42,15: 29,30: 41)$.

\subsection{Third Share: Angelic Proximity}

The servant's final "share" is determined by the effort he exerts acquiring whatever can be acquired of God's attributes, adorning himself with their beauty and attaining a proximity not to God as such, but to His angels. For al-Ghazālī, knowledge of God and the process of takhalluq culminates in a bewildering state of dismay (dahsha, hayra) that we are incapable ('ajz) of truly knowing God, and a certitude that God in Himself cannot be realised. This state of bewilderment captures the simultaneous affirmation and negation of the possibility of knowing God, and it goes hand in hand with the process of discovering the names. For just as the ma'ān $\bar{\imath}$ face two directions (the Essence and the names), the servant faces two infinitudes: there is no end to what we can know about God, just as there is no end to what we cannot know about God. The furthest goal (ghāya) and highest aim of al-Ghazālì's Maqșad is to offer intimations ( $\bar{i} m \bar{a})$ of the keys to unlocking this state of bewilderment by offering synoptic insights into the core creedal beliefs concerning the names (al-Ghazālī 1971, 108, 111).

Theologically speaking, al-Ghazāli never tires of reminding his reader that there is no analogy that can be drawn between the servant and the Lord at this third "share". For in the end, takhalluq is seeking proximity (qurb), i.e., becoming more angelic and less beastly. Those who have the fullest share in the names act as intermediaries between God and human beings. They are vessels through whom God provides, guides, and bestows His outward and inward blessings upon mankind; i.e., the Prophets, the saints, and the scholars. Their "share," or "portion" (hazz) does not denote a "sharing" (mushāraka) in divine character traits. It is not a likening of human attributes to divine attributes, since "to liken" (mumāthala) is to affirm a commensurability of quiddity (mähiyya) or species (naw') between the servant and God.

In true Ash'arī fashion, he argues that logically equivocal terms (mushāraka $f i$ lism) applied to both God and the servant do not bridge the disparity (tafāwut) between the two. Al-Ghazâlī argues that what humans share with God can be compared to accidental qualities (sing. 'arad) which are outside the essential identity of God. For even complete opposites can be alike, and share characteristics: black and white are accidental qualities, colours, perceived by 
eyesight, that inhere in atoms. In a similar sense, we share seven attributes with God, but He is distinguished as the Necessary Being from whom all beings exist (al-Ghazāli 1971, 47). This is why just as a conceptual grasp of the $m a^{\prime} n \bar{a}$ of a name is beyond human reach, when the servant shares in the supra-formal meaning of a name ( $\left.m a^{\prime} n \bar{a}\right)$, he partakes in it in a mode that is characterised by deficiency (naqș), delimitation (taqyìd), shortcoming (taqșir), pretence (takalluf), metaphor (majāz), correlation (id̄a fa); this is in contrast to God's perfection (kamāl), nondelimitation (ițlāq), reality (haqq).

Thus, only God knows His own quiddity (mähiyya). We only know God by name. Yet when we claim to "know God by name," that denotes a certain intimacy with God (after all, we're on a first-name basis with Him) and a distance (for we just know Him by name). The "by-name-ness" of our knowledge of God indicates the simultaneous intimacy and remoteness of our relationship to Him. The names both veil and reveal God's perfection, and although none of the divine names and attributes can be fully known, exhausted, or reduced to meaningless proper nouns, the more one begins to grasp the perfection of the meanings of the divine names, the more one comprehends how short one has fallen. The hierarchical degrees of knowledge and proximity attained by saints and prophets are determined by their verification and knowledge of the properties, effects, and traces of His names:

Indeed, the more a servant comprehends the details of the objects of God's power and the wonders of His artisanry in the kingdom of the heavens, the more plentiful is his share in knowing the attribute of divine power, for the fruit is a proof of the tree. Similarly, the more a student comprehends the details of his teacher's knowledge and writings, the more perfect is his knowledge of him, and the more complete is his esteem for him.

AL-GHAZĀLĪ 1971, 57; modified English trans., 45

As the ancient Greek philosopher Xenophanes (d. 475 BCE) said: "It takes a wise man to recognise a wise man." Echoing a similar sentiment, al-Ghazālī illustrates his point with the following metaphor: both an advanced student and a door keeper know that al-Shāfici is arguably the greatest legal theorist of Islamic history, but the student's knowledge of al-Shāfi'i surpasses that of his door keeper. Thus, al-Ghazāli concludes, we can only truly understand the ma'ān $\bar{\imath}$ of the divine names in relation to a purified self. After all, the names were coined by God in order for us to understand them from our subjective standpoint. The verse nothing is as His like, and He is the Hearing, the Seeing (Q 42:11) captures this fundamental paradox. Our experience of sight (basar) 
communicates something of the divine name the All-Seeing (al-Bașir $)$ by way of metaphor (al-Ghazāli 1971, 117). The first part of the verse, which proclaims God's incommensurability, is immediately followed by commensurable ma'ān $\bar{\imath}$ of hearing and seeing.

Thus, for instance, God is the independent King (al-Malik) of all creation. He is independent in His Essence and His attributes from all existents. Existents, for their part, are needful of Him in their essences and attributes. The servant is forever needful of God, and does not share in God's absolute sovereignty. However, a true king among servants is one who is ruled and possessed by none other than God. Such a servant has no need for anyone else. His "kingdom" consists of his heart and body. His appetites, anger, and passions are his soldiers; his "subjects" are his tongue, eyes, ears, arms, legs, stomach, and sexual organ (al-jawärih). These soldiers and subjects obey a servant who has attained the station of sovereignty. The Prophets, for their part, are the greatest kings on earth, for all are in need of their guidance in this life and the next, and they are followed by the scholars who are their heirs on earth (al-Ghazālī $1971,70)$.

\section{Reception of al-Ghazālì's Doctrine of Takhalluq}

For all its brilliance, the Maqșad as an ethical project is not a particularly unique or groundbreaking intervention in the divine names tradition. Sufi theologians had been meditating on the ethical dictates of the divine names long before and after Hujjat al-Islām's meteoric rise to prominence. ${ }^{35}$ The Maqșad might not have acquired extraordinary fame had it not been for the well-merited fame of its author. However, the commentary was widely read throughout the

35 Aside from meditations on the ethical applicability of the names in Qushayrīs tahbì $r$, this theme is also found in the early writings of Abū Bakr al-Wāsiți (d. 331/942) who considered takhalluq bi-akhlāq Allāh to be the definition of Sufism itself (Shahzad 2004). Moreover, as Atif Khalil notes, the concept of takhalluq is not only generated by meditations on, and interactions with God through His divine names, but by early Sufi ethicists who observe how humans interact with each other. Abū Țālib al-Makkī writes: "If someone were to prepare a meal for you, and you found fault in it and criticised it, he would detest that from you. Similarly, God detests that from you. And this falls into the knowledge of [divine] attributes, and in the meaning behind what has been said, that 'the one most knowledgeable of God is the one most knowledge of himself.'" Al-Makki concludes, "If you were to understand your own attributes through your interactions with created beings, you would come to understand from them the attributes of your Creator" (Khalil 2014). See also al-Makkì's discussion of "assuming the character traits of lordship" (al-takhalluq bi-akhlāq al-rubūbiyya) in Qūt al-qulūb (al-Makkī 2005, 2:362). 
Islamic world, and despite critical reactions to it from a variety of theological viewpoints, it is primarily due to the Maqsad that so many subsequent commentaries feature ethical discussions of the names. This is particularly true in the Islamic West, where Ibn Ṭufayl (d. 581/1185) notes with some concern, that the Maqșad was a widely distributed treatise containing meditations on sensitive matters (Griffel 2000, 401-62). The Maqșad's importance and originality lies in the following: (1) being a widely accessible, well organised, unusually succinct, and easily wielded reference work that most post-Ghazālian commentators referred to. (2) al-Ghazālì's commitment to the term "takhalluq" in his introductory chapter; and (3) his tendency to (over)systematise the divine names discourse.

Let us examine his commitment to the term takhalluq. It is interesting to note that al-Ghazāli employs the term takhalluq extensively in the heart of his theoretical introduction and concluding discussions about ethics. He usually shies away from the term in the actual commentary on the ninety-nine names where he privileges more nuanced and symbiotic expressions like the "share" (hazz) of the servant, or his "access" to (madkhal $f i$ ) the name, or the "possible acquisition" of a trait (al-iktisāb al-mumkin) (al-Ghazālì 1971, 142, 143). Al-Ghazālī readily admits that the term takhalluq is to be used with leniency (tawassu) and by way of metaphor (isti'ära) (al-Ghazālì 1971, 162), and after his commentary on the names, he adds a concluding apologia. It is clear that he employs the term more as a catch-phrase than a scriptural prooftext, but the usage of the term is nonetheless deconstructive. For similarly minded commentators before al-Ghazālī, and many after him, were committed to discussing the ethical consequences of the names but avoided the term because it sounds theologically risqué. Indeed, takhalluq implies a comparable similarity between the qualities of the divine Essence and human character traits, and al-Ghazâli's terminological choice never escapes this stigma of affinity (munāsaba) between the Eternal and the created. Takhalluq, moreover, implies an active and one-sided struggle of the soul in achieving divine character traits, and does not suggest divine grace in this process. Other commentators chose other terms for good reason: al-Qushayrī prioritises the term "etiquette" (adab) or "showing courtesy with respect to" a name (ta'addub), while Ibn Barrajān favours the term "practice of servanthood" (ta'abbud) with regard to a particular name.

It seems that al-Ghazālì's terminological commitment, not his theology, raised a red flag in many circles. It gave certain authors the impression that the Maqșad failed to strike a balance between tashbih and/or tanzīh. The Maqșad raised eyebrows of many later authors, including the Andalusī mystic 
Ibn 'Arabī, ${ }^{36}$ and the Hanbali champion Ibn Taymiyya. ${ }^{37}$ For the latter's followers, such as Ibn al-Qayyim, the term takhalluq indicates that the Maqsad is a philosophically contaminated text. ${ }^{38}$ The term, moreover, is reminiscent of the terms al-ta'alluh, "deiformity" and al-tashabbuh bi-Llāh "striving to achieve similarity with God" that are used by Avicenna in his writings. ${ }^{39}$ Many medieval Islamic authors were also uncomfortable with philosophical ethics because it suggests that ethics can be intellectually reasoned, and that one can therefore dispense with revelation and prophecy. Complaints of this nature are also echoed by Ibn Barrajān. ${ }^{40}$ To be sure, philosophical ethics was

36 See Addas for a discussion of Ibn 'Arabī's understanding of takhalluq (Addas 2015, 24). One of Ibn 'Arabī's earlier works is a commentary on the names which follows tripartite division "realisation, self-characterisation, and attachment" (tahaqquq, takhalluq, ta'alluq), entitled Kashf al-Ma'nā 'an Sirr Asmā̄' Allāh al-Husnā. (Ibn 'Arabī 2010). He restricts himself to the ninety-nine names mentioned by al-Ghazālī in the Maqșad. In his later Futūhạt, however, Ibn 'Arabī uses the term takhalluq quite regularly but expresses some discomfort with it, especially insofar as it is used by al-Ghazālī because he felt that it inevitably implied a tashbih, or correspondence between the eternal Lord and the created servant: "If I ever ascribed correspondence (munāsaba) [between servant and Lord] as Imām Abū Ḥāmid al-Ghazālī does in his books and elsewhere, it is a sort of forced explanation (takalluf) and a far cry from the realities [that we intend to express], for what correspondence is there between the temporally originated and the eternal, and how can one compare anything to that which resists all comparison?" The passage in question is found in the first "part" or faṣl of the Futūhāt, known as al-fașl al-awwal, fi l-Ma'ārif, which is spread over the first 73 chapters; see Chapter Three (al-bāb al-thālith), entitled Fì tanzīh al-Haqq.

37 Ibn Taymiyya criticises the term takhalluq for being a carry-over from philosophy, and had a strong distaste for Ghazālì's hyper-theologised understanding of God's attributes and his doctrine of takhalluq. Ironically, he critiques the anti-anthropopathism of Ash'arīs and accuses them of tat till, or denying essential attributes of God that He ascribes to Himself, such as mercy, love, and anger. (Ibn Taymiyya 2005, 7:413-416).

38 Ibn al-Qayyim objected to the project as it seems to build off philosophical ethics of Miskaway's Tahdhïb al-Akhlāq ("Refinement of Character Traits").

39 See Avicenna's Risāla fì l-ishq ("Treatise on Love") where he speaks of achieving conformity with qualities of the Necessary Being as a process of "deiformity" (ta'alluh). He describes the Necessary Being as the True Lover, and the process of becoming characterised by its qualities as an actualisation of Necessary Being's love for beauty, and affirms that the attributes of the Necessary Being (unity, generosity, wisdom, eternity etc.) can be conformed to (Chittick 1995).

40 Ibn Barrajān (d. 536/1141), who did not read the Maqșad when writing his own massive and seminal commentary on the divine names, had theological misgivings about the term takhalluq because ascribing "character traits" to God struck him as anthropomorphic, and he found such discourse to be uncomfortably close to philosophical discourse. (Casewit $2017,136-55$ ). For a study of theological responses to this theological problem (see Gimaret 1997). 
certainly part and parcel of the educational background that al-Ghazālī inherited, and Greek ethics easily lends itself to Islamic ethics. Like so many authors, it impacts how he formulates, codifies, and classifies ethics. He found Plato's tripartite division of the faculties of the soul in The Republic, the four cardinal virtues, and Aristotle's virtue as a golden mean between excess (ifrät $t$ ) and deficiency (tafrit t) to be a useful way of discussing and framing the virtues. But despite common terms and the use of parallel formulations in philosophical ethics and takhalluq discourse, as well as al-Ghazālī's demonstrable familiarity with philosophical ethics in the Ihy $\vec{a}$, this accusation is a red herring that distracts from the core theological concerns and dynamics that undergird al-Ghazālī's Maqșad. ${ }^{41}$

Hesitations over using the term takhalluq are expressed by al-Ghazāli's own student, Abū Bakr b. al-'Arabī. The latter is alert to the problematic nature of the term takhalluq in his ethical meditations on the names, and expresses his reservations in his remarkable commentary, al-Amad al-Aqșa ("The Furthest Limit") (Ibn al-'Arabī, 2015, 1:230-231). Tellingly, Ibn al-'Arabī introduces his ethical discussion with a section devoted to "the exclusively divine traits of God" (ikhtișāṣāt ilāhiya), and under the heading: "supreme station of the Lord" (al-manzila al-ulya lil-Rabb) in contrast to the "lowly station of the servant" (al-manzila sufla lil-'abd). ${ }^{42}$

It seems that this terminological use incited the ire of the Tunisian Mālikī jurist al-Māzirī (d. 536/1141). ${ }^{43}$ Al-Ghazālī is the first to concede that some "shares" of a servant in names is by way of a "far-fetched metaphor" (majāz

41 Our author was surely aware of al-Rāghib al-Iṣfahānīs Kitāb al-Dharīa ilā Makārim al-Sharī'a, a book that influenced al-Ghazālì's Mìzān al-Amal on science of the soul, the house, and society. It may have also played a role in informing al-Ghazālī's takhalluq, since it mentions the notion of "emulating God to the extent of one's ability" (al-iqtida bi-Llāh bi-qadr al-țāqa). Miskawayh's Tahdhīb al-akhlāq would have been known to him as well.

42 Abū Bakr b. al-'Arabī devotes a section to the distinctive features of God's akhlāq (ikhtișāṣāt ilähiya) to stress the Lord's transcendence (al-manzila al-'ulyā lil-Rabb) in contrast to the lowly station of the servant (manzila sufla lil-'abd). The Amad is structured much like the Maqșad with theological introductions, and commentaries on Qurānic verses like the Tahbir of al-Qushayrī. The names are listed in degrees of ascent (taraqqī) in devotion. Each name receives four separate commentaries: 1) scriptural root (mawrid); 2) philological analysis (lugha);3) theological analysis tracing each name's relation to the attributes and Essence; 4) divine assumption of traits (takhalluq) and al-manzila al-ulyā lil-'abd; to address how God shares in the character trait without being anthropopathic, followed by 5) human share in the name.

43 See Ibn Taymiyya 2010, 6:124-126. According to Ibn Taymiyya, Makkīs discussions of takhalluq in the Qūt al-Qulūb were also refuted by the Shāfi'i Sufi traditionist Abū l-Bayān al-Dimashqī, known as Ibn al-Ḥamrāwī (d. 551/1156). 
ba'id), such as the Creator (al-Khäliq) and the Author (al-Bāri'); we employ our power in light of our knowledge, just like God. For al-Māzīrī, the names of majesty are specific to God, by consensus, and the servant has no share in them. One can emulate the character traits of the Prophet but not of God, for nothing is as His like (Q 42:11). Hence holy sayings such as "Majesty is My cloak, and greatness is My robe, and he who competes with Me in respect of either of them, I shall punish." ${ }^{44}$ When discussing the servant's share in God's name the Compeller ( $a$ l-Jabbār $)$, he states that the Prophet embodies this name because he is followed, emulated, obeyed, imitated, peerless in rank and in behaviour, for he cannot be matched by anyone (al-Ghazālī 1971, 78-79).

Al-Māzirì's criticism foregrounds the criticism of traditionalist Ahl al-Hadìth scholars. The latter, who are not committed to the Ash'arī doctrine, raise objections regarding the extent to which takhalluq can be applied to all the names. Can the servant acquire a share in all divine character traits, including those of majesty and grandeur? Generally speaking, most scholars accept that the servant can take on some characteristics of God. But while the principle of takhalluq is generally accepted, extending it to all the names including those of majesty and transcendence is criticised by many as being a "forced explanation," or a stilted exercise in enforced clarity (takalluf). ${ }^{45}$ From the perspective of Ibn Taymiyya and Ibn al-Qayyim, for instance, al-Ghazäli’s theological systematisation of takhalluq in the language of Ash'arī volitionism failed to make a convincing case for how all the divine names-including the names of majesty and transcendence - can be used as a source of moral guidance. Ahl al-Hadìth authors were wary of the Maqșad's heavy layer of Ash'arism and

44 Ibn Māja, Sunan, kitāb al-zuhd, no. 4314.

45 Al-Ghazālī applies takhalluq to each name, and it works theologically within the Ash'arī volitionist framework. For the Ahl al-Hadith who reject the theological underpinnings of this discourse, this is criticised for being a stretch. However, he also holds that there is no possible takhalluq for the name Allāh for a few reasons. First, as we saw above, he is inclined to consider this name, as well as the name the All-Merciful (al-Rāhmān), to "follow the pattern of proper nouns" ('alā majrā asmāa' al-'alam) and that Allāh does not have an etymological root. Second, it is the all-encompassing name and thus it is hallowed beyond the reach of the servant. Here, al-Ghazāli is aligning himself with the early Sufi tradition. In al-Sulamì's Qur'ān commentary, Haqā'iq al-Tafsìr, the possibility of taking on the character traits of all the names except for the divine name Allāh is articulated, and is attributed to early Sufi Abū Bakr al-Wāsițī (d. 331/942). For Allāh is the all-encompassing name that brings together attributes of Divinity, Lordship and Reality. If one may speak of a "share" of a servant in this name, it is to have a heart that is completely immersed in God, to aspire to Him alone, to see none but Him, to fear none but Him, to recognise that everything other than Him, including oneself, is passing away here and now and is only real insofar as it is sustained by Him (al-Sulamī 2001, 1:31). For pre-Qushayrian discussions of takhalluq see (Massignon 1999, 284; 1922, 3:142, 287). 
critiqued al-Ghazālī for excessive tanzīh, or denying the attributes $\left(\operatorname{tat}^{\mathrm{t}} \mathrm{t} l\right)$ by reducing names such as the Loving-Kind ( $a$-Wadūd) to the divine will.

The second distinguishing feature of the Maqsad is thus its enforcement of an over-systematised and hyper-theologised hermeneutics. Al-Ghazālī demonstrates a consistent, rigorous, and rigid theological commitment to the concept of takhalluq as an ethical principle, and he binds himself to his self-prescribed hermeneutical principles. It is interesting that Ibn 'Arabī and some of his followers, including his disciple al-Qūnawī, generally adopted al-Ghazālī's theory that each name has one overarching meaning in their commentaries on the divine names. In contrast, similarly-minded Ash'arī commentators who engaged with the Maqsad usually pushed against his hermeneutics and valued methodological leniency. Abū Bakr b. al-'Arabī avoids synonymity in al-Amad $a l-A q s ̦ \bar{a}$ but not as consistently as al-Ghazālī. Likewise, Ibn al-Uqlīshī affirms polysemy and synonymity in his commentary and states that al-Ghazālì's rigid hermeneutics pre-emptively close doors of our understanding of the names (Ibn al-Uqlīshī 2017, 1: 244).

Meditations on the significance of the divine names can be traced back to the earliest period of Islamic thought. However, by the Islamic Middle Period, the divine names genre takes on a life of its own, as evidenced by the composition of independent commentaries rather than sections of larger theological works. These commentaries, moreover, tended to be meditative texts produced at the hands of well-rounded and senior scholars. By their very nature, the divine names tradition falls somewhat outside the realm of formal theology. It attracts less polemics and is not primarily concerned with establishing tight theological proofs. For the commentators, "reckoning the names" (ihșa $\bar{a}^{2}$ al-asma $\vec{a}^{\prime}$ ) was often understood as a door to paradise by applying all of one's learning and spiritual training to understand an aspect of God's relation to the human soul and creation.

Al-Ghazālī's drive for systematisation produced a commentary that was both valued for its concision and clarity, as well as criticised for the limits it placed on interpreting the divine names. Despite its heavy-going theological concerns, however, it should be emphasised that the Maqșad was also written with devotional ends in mind. Al-Ghazālī often sets aside polemics and technical theological debates. ${ }^{46}$ But in affirming the divine roots of human ethics,

46 Al-Qushayrī too has theological arguments and refutations in his Tahbir r, but they are secondary to his purpose (e.g., al-Qushayrī 1986, 103). Abū Bakr b. al-'Arabī also refutes the 
he can never fully put his theological concerns to rest. He employs the theological, philosophical, and juridical (ușülī) tools at his disposal to systematise the analogical process of reasoning about the divine names. This Ghazālian drive in the Maqsad (completed ca. 495-499/1101-1105) is also detectable in his approach to the Qur'ānic exegetical tradition in his Qānūn al-Ta'will ("The Rule of Interpretation," completed ca. 490/1097). For in the Qānūn, he seeks to determine the correct reading of the Qur'ān, just as in the Maqșad he seeks to determine the only correct meaning of a name by laying out "rules of interpretation" of the names. ${ }^{47}$ These hermeneutical principles guide his approach to acquiring character traits of God through analogical knowledge. Al-Ghazālī thus approaches virtue ethics almost as a legal theorist $(u s \underline{u} / \bar{\imath})$ would, by drawing analogy from the visible (i.e., the human ethical share in the meaning of a name) for the unseen (the transcendent mána of the name) (qiyās al-shähid 'alā al-ghäib). But in the end, the transcendent names are resistant to such meta-hermeneutics and cannot be confined to neat rational categories.

\section{Bibliography}

Addas, Claude. 2015. La maison muhammadienne: aperçus de la dévotion au Prophète en mystique musulmane. Paris: Gallimard.

al-Albānī, Muḥammad Nāṣir al-Dīn. 20oo. Silsilat al-Ahādīth al-Dạî̉a wa-l-Mawḍ̂̄a, 15 vols. Riyad: Maktabat al-Maārif.

al-Ash'arī, Abū l-Hasan. 1969. Maqualät al-Islämiyyīn wa-Khtiläf al-Mușallīn, edited by Muhammad Muhyī l-Dīn 'Abd al-Ḥamīd. Cairo: Maktabat al-Nahḍa al-Miṣriyya.

Ayed, Nejib. 1983. Kalām \& Tașawwuf: Essai sur les rapports entre l'ašarisme et le șüfisme à travers l'ouvre d'Abū l-Qāsim al-Qušayrī (376-465/986-1072). Ph.D. Dissertation. Université Paris Sorbonne.

al-Bukhārī, Muḥammad b. Ismācill. 20oo. Șaḥ̄h, 3 vols. Vaduz, Lichtenstein: Thesaurus Islamicus Foundation.

Casewit, Yousef. 2017. The Mystics of al-Andalus: Ibn Barrajān and Islamic Thought in the Twelfth Century. Cambridge: Cambridge University Press.

Chiabotti, Francesco. 2017. "Éthique et théologie: la pratique de l'adab dans le traité sur les Noms divins d'Abū l-Qāsim 'Abd al-Karīm al-Qushayrī (al-Tahbịr fì i ilm

Qadarīs repeatedly over the question of freewill. Names like the King (al-Malik) and the Creator (al-Khäliq) occasion this type of theological refutation.

47 In the Qānün he reasons that passages that do not contradict reason are to be understood in their literal sense; those that are contradicted by reason are to be understood in an esoteric figurative sense; and those that cannot be affirmed or contradicted by reason are to be understood in a literal sense. On al-Ghazālì's universal rule of interpreting revelation in Qānūn al-Ta'wül (see Griffel 2009, 70). 
al-tadhkirr)." In Ethics and Spirituality in Islam: Sufi Adab, edited by Francesco Chiabotti et al., 165-197. Leiden: Brill.

Chittick, William. 2019. The Repose of the Spirits: A Sufi Commentary on the Divine Names. Albany: State University of New York Press.

Chittick, William. 1995. "Divine Roots of Human Love." Journal of Muhyiddin Ibn Arabi Society 17: $55^{-78 .}$

Chittick, William. 1989. The Sufi Path of Knowledge: Ibn al-Arabìs Metaphysics of Imagination. Albany: State University of New York Press.

Ebstein, Michael. 2018. "'In Truth You are the Polytheist!': Mythic Elements in Ibn al'Arabì's Teachings on the Divine Names." Intellectual History of the Islamicate World $6(3): 359-387$.

Frank, Richard. 1992. Creation and the Cosmic System: Al-Ghazâlî and Avicenna. Heidelberg: Carl Winter Universitätverlag.

Frank, Richard. 1978. Beings and their Attributes: The Teaching of the Basrian School of the Mu'tazila in the Classical Period. Albany: New York State University Press.

al-Ghazālī, Abū Ḥāmid. 2011. Ihyyā' 'Ulūm al-Dìn, 10 vols. Beirut: Dār al-Minhāj. al-Ghazālī, Abū Ḥāmid. 2008. Al-Iqtiṣād fì l-I'tiqād, edited by A. M. 'A. al-Sharqāwī. Jeddah: Dār al-Minhāj.

al-Ghazālī, Abū Hāmid. 2013. The Jewels of the Qur'ān: al-Ghazālì’s Theory, translated by Muhammad Abul Quasem. Kuala Lumpur: Islamic Book Trust.

al-Ghazālī, Abū Ḥāmid. 1995. The Ninety-Nine Beautiful Names of God: al-Maqșad al-Asnā fı̀ Sharh Asmā’ Allāh al-Husnā, translated by David Burrell and Nazih Daher. Cambridge UK: Islamic Texts Society.

al-Ghazālī, Abū Ḥāmid. 1971. Al-Maqșad al-Asnā fì Sharh Ma'ānī Asmā’ Allāh al-Husnā, edited by Fadlou Shehadi. Beirut: Dār el-Mashriq.

al-Ghuṣn, 'Abd Allāh b. Șāliḥ. 1996. Asmā̄’ Allāh al-Husnā. Riyad: Dār al-Wațan.

Gimaret, Daniel. 1997. Dieu à l'image de l'homme. Les anthropomorphismes de la Sunna et leur interprétation par les théologiens. Paris: CERF.

Gimaret, Daniel. 1988. Les noms divins en Islam: exégèse lexicographique et théologique. Paris: CERF.

Gramlich, Richard. 1995. Alte Vorbilder des Sufismus. Erste Teil. Scheiche des Westens. Wiesbaden: Harrassowitz.

Griffel, Frank. 20og. Al-Ghazālì's Philosophical Theology. Oxford and New York: Oxford University Press.

Griffel, Frank. 200o. Apostasie und Toleranz im Islam: die Entwicklung zu al-Ġazātiss Urteil gegen die Philosophie und die Reaktionen der Philosophen. Leiden and Boston: Brill.

Güleçyüz, Mehmet Emin. 2018. Mütekaddimîn Dönemi Eş’arî Kelâmında Beşerî Duyguların Allah'a Nisbeti Meselesi. MA Thesis, Istanbul 29 Mayis University. 
Ibn al-Arabī, Abū Bakr. 2015. al-Amad al-Aqșā fí Sharh Asmā̄ Allāh al-Husnā wa-Ṣifātih al-'Ulā, edited by 'Abd Allāh al-Tawrātī and Aḥmad al-'Arrūbī, 2 vols. Rabat: Dār al-Amān.

Ibn 'Arabī, Muhyī l-Dīn. 2010. Al-Futūḥāt al-Makkiyya, edited by 'Abd al-'Azīz Sulțān al-Manșūb, 12 vols. Tarim: Wizārat al-Thaqāfa.

Ibn 'Arabī, Muhyȳ l-Dīn. 2010. Le Secret de Noms de Dieu, edited and translated by Pablo Beneito. Paris: Albouraq.

Ibn 'Arabī. Muḥyī l-Dīn. 1996. Kitāb Kashf al-Ma'nā 'an Sirr Asmā' Allāh al-Husnā, edited by Pablo Beneito, El secreto de los nombres de Dios. Murcia: Editora Regional de Murcia.

Ibn Hanbal, Aḥmad. 2006. Al-Musnad, 12 vols. Vaduz, Lichtenstein: Thesaurus Islamicus Foundation.

Ibn Taymiyya, Taqī al-Dīn. 2010. Jāmi` al-Masāill, edited by Muhammad 'Uzayr Shams and Bakr b. 'Abd Allāh Abū Zayd, 6 vols. Makkah: Dār 'Ālam al-Fawāiid.

Ibn Taymiyya, Taqī al-Dīn. 20o6. Talbìs al-Jahmiyya fì Ta’sīs Bida'ihim al-Kalāmìyya, 10 vols. Medina: King Fahd Press.

Ibn Taymiyya, Taqī al-Dīn. 2005. Bayān Talbīs al-Jahmiyya fì Ta’sis Bidacihim alKalāmiyya, edited by Muḥammad al-Buraydī. Medina: Majma' al-Malik Fahd li-Ṭibācat al-Muṣḥaf al-Sharīf.

Ibn Taymiyya, Taqī al-Dīn. 1965. Sharh al-'Aqìda al-Așfahāniyya, edited by Makhlūf Hasanayn Hasan. Cairo: Dār al-Kutub al-Hadìtha.

Ibn al-Uqlīshī, Aḥmad b. Ma'add. 2017. Al-Inbā’ fì Sharh Haqā’iq al-Ṣifāt wa-l-Asmāà, edited by Aḥmad Rajab Abū Sālim, 2 vols. Kuwait: Dār al-Ḍiyā’.

Janssens, Jules. 2014. "Éléments Avicenniens dans le livre al-Maqșad d'al-Ghazālī." Mélanges de l'Institut Dominicain d'Études Orientales 30: 91-103.

al-Juwan̄̄, Abū l-Ma'ālī 'Abd al-Malik. 1950. Al-Irshād ilā Qawāți al-Adilla fì Ușūl al-I'tiqād, edited by Muhammad Yūsuf Mūsā and 'Alī 'Abd al-Mun'im 'Abd al-Ḥamīd. Cairo: Maktabat al-Khānjī.

Khalil, Atif. 2014. "Contentment, Satisfaction, and Good-Pleasure: Rid̄a in Early Suf Moral Psychology." Studies in Religion 43(3): 371-389.

Kukkonen, Taneli. 2011. "Al-Ghazālī on Accidental Identity and the Attributes." The Muslim World 101(4): 658-679.

Kukkonen, Taneli. 2010. "Al-Ghazālī on the Signification of the Names." Vivarium 48(1-2):55-74.

Maghsoudlou, Salimeh. 2017. "Étude des doctrines du nom dans al-Maqșad al-asnā d'al-Ghazālī et de leur origine théologique et grammaticale." Studia Islamica 112(1): 29-75.

al-Majlisī, Muḥammad Bāqir. 1983. Biḥ̂̄r al-Anwār al-Jāmi'a li-Durar Akhbār al-A’imma al-Ațār, 110 vols. Beirut: Dār Iḥyā' al-Turāth al-'Arabī. 
al-Makkī, Abū Țālib. 2005. Qūt al-Qulūbfì Mu'āmalatal-Maḥbūbwa-WasfṬarīq al-Murīd ilā Maqām al-Tawhīd, edited by 'Āṣim Ibrāhīm Kayyālī, 2 vols. Beirut: Dār al-Kutub.

Massignon, Louis. 1999. Essai sur les origins du lexique technique de la mystique musulmane. Paris: CERF.

Massignon, Louis. 1922. La Passion de Hallâj, martyr mystique de l'Islam exécuté à Bagdad le 26 mars 922, 3 vols. Paris: Geuthner.

al-Mizzī, Jamāl al-Dīn Yūsuf. 1983. Tuhfat al-Ashrāf, edited by A. Sharaf al-Dīn, 14 vols. Bombay: al-Dār al-Qayyima.

Muslim Ibn al-Hajjāj al-Naysabūrī. 200o. Șaḥ̄h, 2 vols. Vaduz, Lichtenstein: Thesaurus Islamicus Foundation.

al-Qushayrī, Abū l-Qāsim. 2003. Al-Risāla al-Qushayriyya, edited by 'Abd al-Ḥalīm Maḥmūd. Damascus: Dār al-Fikr.

al-Qushayrī, Abū l-Qāsim. 1986. Sharh Asmāà Allāh al-Husnā. Beirut: Dār Āzāl.

al-Rāzī, Fakhr al-Dīn. 1905. Lawāmi` al-Bayyināt: Sharḥ Asmā’ Allāh Tàălā wa-l-Ṣifāt. Cairo: al-Mațba'a al-Sharafiyya.

al-Sam'ānī, Ahmad. 2019. The Repose of the Spirits: A Sufi Commentary on the Divine Names. Translated by William Chittick. Albany: State University of New York Press. Shahzad, Qaiser. 2004. Ibn 'Arabī's Contribution to Ethics of Divine Names. Islamic Studies 43(1):5-38.

al-Sulamī, Abū 'Abd al-Raḥmān. 2001. Tafsìr al-Sulamī wa-Huwa Haqā̇iq al-Tafsìr, 2 vols. Beirut: Dār al-Kutub al-'Ilmiyya.

al-Tirmidhī, Muḥammad b. '̄̄sā b. Sawra. 200o. Sunan, 2 vols. Vaduz, Lichtenstein: Thesaurus Islamicus Foundation.

van Ess, Josef. 1991-1997. Theologie und Gesselschaft im 2. und 3. Jahrhundert Hidschra, 6 vols. Berlin: Walter de Gruyter.

Zargar, Cyrus Ali. 2017. The Polished Mirror: Storytelling and the Pursuit of Virtue in Islamic Philosophy and Sufism. London: Oneworld Publications. 